\title{
The southern Weddell Sea: combined contourite-turbidite sedimentation at the southeastern margin of the Weddell Gyre
}

\author{
K. H. MICHELS*, G. KUHN, C.-D. HILLENBRAND, B. DIEKMANN, D. K. FÜTTERER, H. GROBE \& \\ G. UENZELMANN-NEBEN \\ Alfred Wegener Institute for Polar and Marine Research, Columbusstr., D-27568 Bremerhaven, Germany (e-mail: \\ kmichels@awi-bremerhaven.de)
}

\begin{abstract}
Sedimentary processes in the southeastern Weddell Sea are influenced by glacial-interglacial ice-shelf dynamics and the cyclonic circulation of the Weddell Gyre, which affects all water masses down to the sea floor. Significantly increased sedimentation rates occur during glacial stages, when ice sheets advance to the shelf edge and trigger gravitational sediment transport to the deep sea. Downslope transport on the Crary Fan and off Dronning Maud and Coats Land is channelized into three huge channel systems, which originate on the eastern, the central and the western Crary Fan. They gradually turn from a northerly direction eastward until they follow a course parallel to the continental slope. All channels show strongly asymmetric cross sections with well-developed levees on their northwestern sides, forming wedge-shaped sediment bodies. They level off very gently. Levees on the southeastern sides are small, if present at all. This characteristic morphology likely results from the process of combined turbidite-contourite deposition. Strong thermohaline currents of the Weddell Gyre entrain particles from turbidity-current suspensions, which flow down the channels, and carry them westward out of the channel where they settle on a surface gently dipping away from the channel. These sediments are intercalated with overbank deposits of high-energy and high-volume turbidity currents, which preferentially flood the left of the channels (looking downchannel) as a result of Coriolis force. In the distal setting of the easternmost channel-levee complex, where thermohaline currents are directed northeastward as a result of a recirculation of water masses from the Enderby Basin, the setting and the internal structures of a wedge-shaped sediment body indicate a contourite drift rather than a channel levee. Dating of the sediments reveals that the levees in their present form started to develop with a late Miocene cooling event, which caused an expansion of the East Antarctic Ice Sheet and an invigoration of thermohaline current activity.
\end{abstract}

\section{Geological and oceanographic setting}

The Weddell Sea is a large marginal sea of the Southern Ocean, bounded in the south by the large Filchner and Ronne Ice Shelves, in the west by the Antarctic Peninsula, and in the north by the South Scotia Ridge (Fig. 1). To the northeast it opens to the South Atlantic, whereas in the SE Coats Land and Dronning Maud Land form its boundary. These coastal areas are part of the East Antarctic shield, which is built up of crystalline Precambrian basement overlain by undeformed sedimentary rocks of the Devonian to Triassic Beacon Supergroup and by mid-Jurassic tholeiitic intrusions and flood basalts (British Antarctic Survey 1985; Tingey 1991). The coast of Coats Land and Dronning Maud Land is characterized by large fringing ice shelves.

The general oceanographic circulation in the Weddell Sea is dominated by the cyclonic Weddell Gyre, which affects all water masses down to the seafloor (Carmack \& Foster 1975a, $b$; Deacon 1979; Gordon et al. 1981). For a detailed review of the Weddell Sea oceanography see Fahrbach et al. (1998). The following section summarizes the most important features.

The Weddell Sea is known as an important area for bottomwater formation; about $70 \%$ of the Antarctic Bottom Water formation is influenced by processes in the Weddell Sea (Carmack \& Foster 1977). The uppermost water mass in the southeastern Weddell Sea is the Winter Water (WW), a residual layer (100-200 $\mathrm{m}$ thick) formed in winter during sea-ice formation. By mixing with Warm Deep Water (WDW) in 200 to $1500 \mathrm{~m}$ water depth, it contributes to the formation of a thin layer of Modified Warm Deep Water (MWDW), located between WDW and WW. The Antarctic Bottom Water (AABW) occurs below $1500 \mathrm{~m}$ water depth down to the sea floor and forms the deepest water mass in the eastern and southeastern Weddell Sea. The Antarctic Coastal Current mainly comprises Eastern Shelf Water (ESW), and follows the contours of the coast on its way through the Weddell Sea, until it reaches the Crary Trough where a major branch turns south. ESW and Western Shelf Water (WSW) from the shelf areas
Table 1. Principal characteristics

\begin{tabular}{ll}
\hline $\begin{array}{l}\text { Location } \\
\text { Setting }\end{array}$ & $\begin{array}{l}\text { Southern Weddell Sea } \\
\text { Southern margin of the cyclonic Weddell } \\
\text { Gyre: important area of bottom water } \\
\text { formation }\end{array}$ \\
$\begin{array}{l}\text { Apper Miocene to Recent } \\
\text { Drift type }\end{array}$ & $\begin{array}{l}\text { Combined contourite-turbidite sedimentation } \\
\text { in levees along the western side of turbiditic } \\
\text { channels } \\
\text { Several tens of kilometres wide, several } \\
\text { hundreds of kilometres long } \\
\text { Dow-amplitude, continuous, thin-layered } \\
\text { reflectors in wedge-shaped sediment bodies } \\
\text { Seismic characteristics }\end{array}$ \\
Sediment characteristics & $\begin{array}{l}\text { Fine-grained terrigenous, moderately to well } \\
\text { sorted, generally not bioturbated, } \\
\text { development mainly during glacials }\end{array}$ \\
\hline
\end{tabular}

west of the Crary Trough circulate under the Filchner and Ronne Ice Shelves, and it is mainly WSW which contributes to the formation of Ice Shelf Water (ISW) by mixing processes. The ISW flows along the western slope of the Crary Trough in water depth of 300 to $800 \mathrm{~m}$ and leaves it to the north across the sill, where it contributes to the formation of Weddell Sea Bottom Water (WSBW), by mixing with WDW (Foldvik et al. 1985). The WSBW forms a water mass underlying the $\mathrm{AABW}$ in the western and northern Weddell Sea. The downslope flow of ISW and/or WSBW in the southern Weddell Sea influences sediment transport processes, especially in the channels and gullies on the continental slope. Sea ice generally covers more than $80 \%$ of the Weddell Sea in the austral winter (Sea Ice Climatic Atlas 1985). Early in the austral spring season a polynya develops along the shelf off Dronning Maud Land and expands southwestward, reaching a width of $200 \mathrm{~km}$ (Zwally et al. 1985; Gloersen et al. 1992). Other areas in the southwestern Weddell Sea generally are still covered 


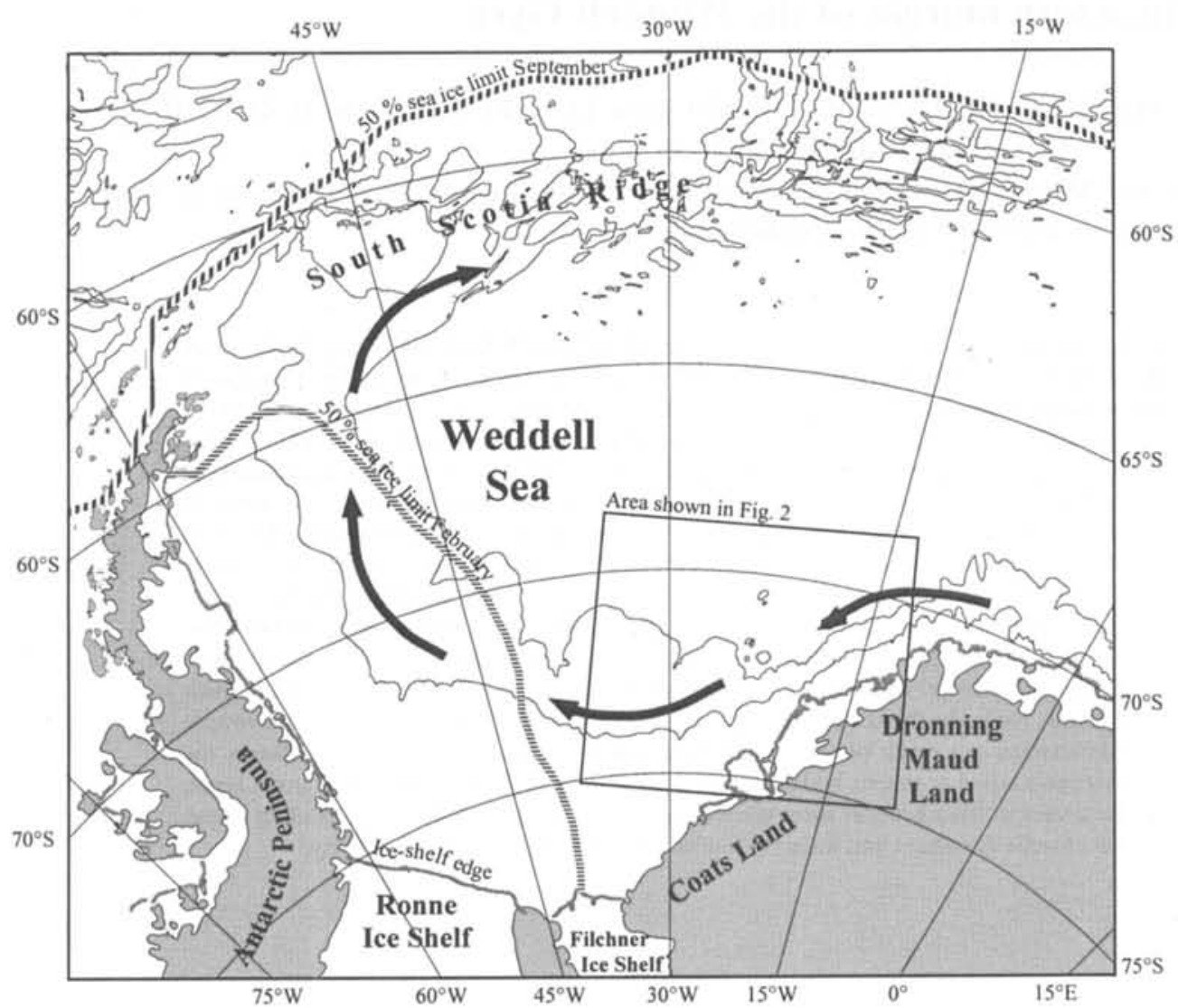

Fig. 1. Map of the Weddell Sea with main geographic features, ocean surface circulation (arrows), and maximum and minimum sea-ice coverage indicated by mean $50 \%$ February and September sea-ice limits (data from Zwally et al. 1985; extracted from Ocean Data View, Schlitzer 1999). Water depth indicated by $2000 \mathrm{~m}$ and $4000 \mathrm{~m}$ isobaths. Box marks area shown in Figure 2. with sea ice to more than $50 \%$ during the minimum sea-icecoverage in mid-February.

\section{Current measurements}

Long and short-term current-meter records have been obtained from the southeastern Weddell Sea during the last two decades. The current meters deployed off Cape Norvegia were part of a transect crossing the Weddell Sea to the northern tip of the Antarctic Peninsula. The results for the Cape Norvegia region indicate very strong southwestward currents on the shelf and along the continental slope (Fahrbach et al. 1994). For presentation here we have chosen three records of mean daily current speed from moorings off Coats and Dronning Maud Land (Fig. 3, see Fig. 2 for location of moorings; data available by courtesy of G. Rohardt, AWI). An almost year-long current speed record from the shelf off Vestkapp is shown in Figure 3a. Strong southwesterly currents with speeds of up to $24 \mathrm{~cm} \mathrm{~s}^{-1}$ dominate the record. An apparent temporal asymmetry characterizes the speeds and directions. In the first half of 1987 the currents were much stronger and showed less deviation from the southwesterly direction than in the second half of 1987 , where current speeds decreased significantly and northerly burst can be found. This is consistent with the observation of Foster \& Middleton (1979) and Fahrbach et al. (1992) that currents show annual variations with stronger currents in the austral summer.

Figure 3 b shows a current-intensity record from the continental slope off Vestkapp (Fahrbach \& Rohardt 1988). The data show a fluctuation of alternating southwesterly and northwesterly directions in a time period band of 15 days (more clearly visible in a plot of the six hourly mean current speed; see Fahrbach et al. 1992, their fig. 11). Foster \& Middleton (1979) discuss basin modes or eddies as possible mechanisms for the fluctuations, whereas Fahrbach et al. (1992) assume that wind forcing plays an important role in the generation of these fluctuations.

The data of mooring AWI 213, which was located in a distal channel of the Crary Fan system, show that current direction and intensity can be variable in the basin (Fig. 3c). Two preferential directions of the flow, northeastward and southwestward, can be attributed to the channel alignment. Weber et al. (1994) ascribed the dominating northeasterly flow to downstreaming ISW from the Filchner shelf via the Crary Fan channel system, but measurements of water mass properties revealed that the current mainly comprises recirculating water masses originating in the Enderby Basin (Hoppema et al. 1998). Hence, the dominating northeasterly current direction probably reflects the local current pattern affected by the topography (Fahrbach et al. 1998).

\section{Bathymetry}

The shelf in this area is relatively narrow with water depths of 300 to $400 \mathrm{~m}$, dipping gently toward the coast as a result of glacial erosion and glacio-isostatic loading. A distinct shelf break in about $600 \mathrm{~m}$ water depth separates the shelf from the steep upper continental slope with inclinations of up to $16^{\circ}$. Along Dronning Maud Land, the midslope includes a terrace dipping seaward at $1.5^{\circ}$ between 1500 to $3000 \mathrm{~m}$ water depth. The lower slope is formed by the Explora Escarpment (Hinz \& Krause 1982; Henriet \& Miller 1990), a steep clifflike slope (up to $30^{\circ}$ ) (Fütterer et al. 1990), abruptly rising from the Weddell Abyssal Plain in c. $4400 \mathrm{~m}$ water depth. Several canyons incise the escarpment, but only the Wegener Canyon at $\sim 14^{\circ} \mathrm{W}$ is important for regional sediment transport (Fig. 2).

Farther south, along Coats Land, the midslope and lower slope are less steep than the upper slope, until they merge into the Crary Fan, a large deep sea fan seaward of Crary Trough in front of the Filchner Ice Shelf. Here the shelf broadens to almost 400 $\mathrm{km}$. Crary Trough is a shelf feature formed by ice erosion. At the Filchner ice-shelf edge it reaches $1200 \mathrm{~m}$ water depth. The transition from the trough to the fan is formed by a sill with water depths of $\sim 600 \mathrm{~m}$. Trough and sill are thought to be the result of both isostatic downwarping beneath the ice masses and glacial 


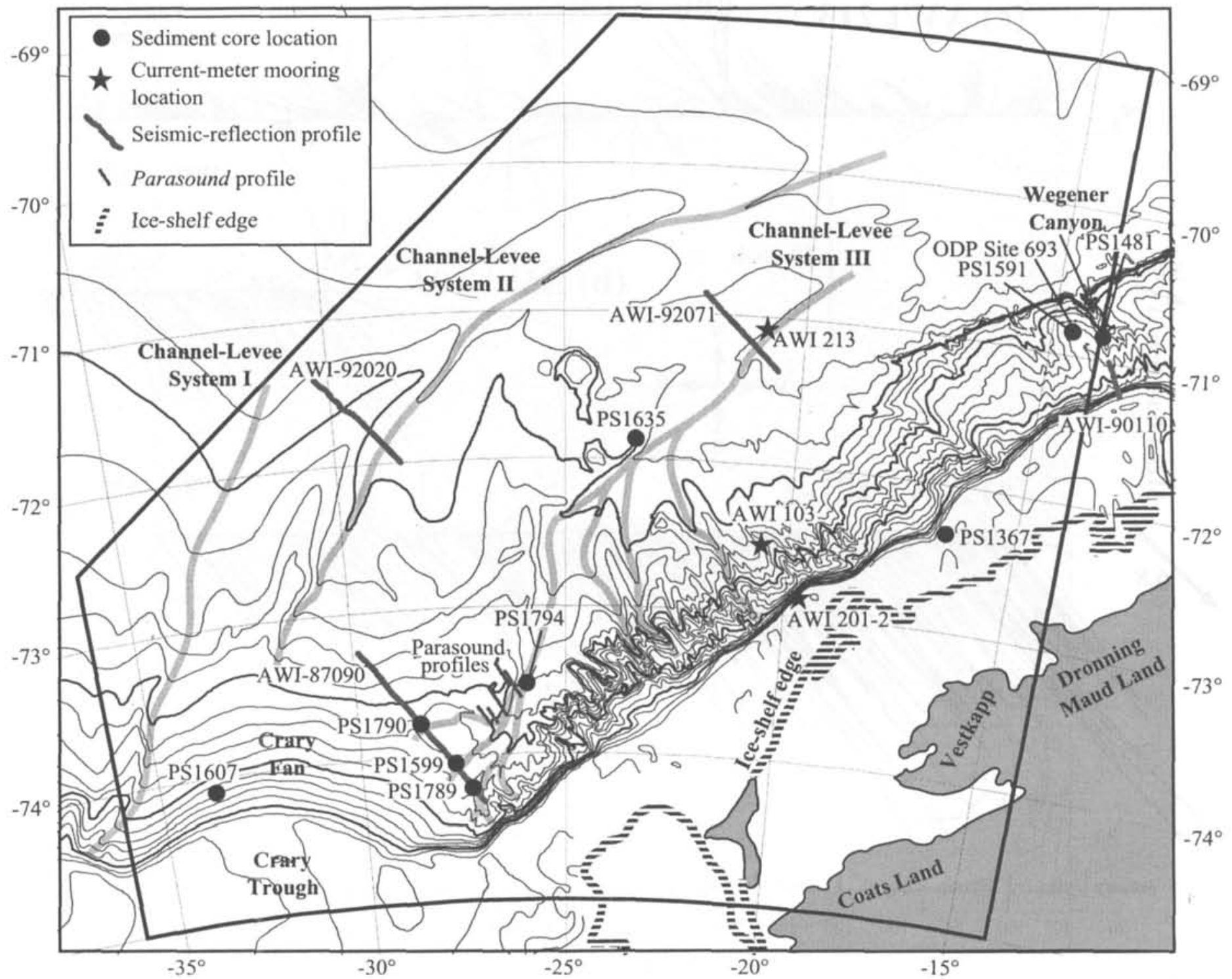

Fig. 2. Map of the southeastern Weddell Sea with main geographic features, courses of Channel-Levee Systems I to III (light grey lines), positions of sediment cores (dots), current-meter moorings (stars), and seismic profiles (dark grey lines) (Schenke et al. 1998). Bathymetry is indicated by isobaths in $200 \mathrm{~m}$ steps, with thick lines every $1000 \mathrm{~m}$. Box marks area shown in Figures 5a, b \& c.

erosion during times when the ice sheet reached further north (Anderson et al. 1983; Elverhøi 1981; Elverhøi \& Maisey 1983; Fütterer \& Melles 1990; Kuvaas \& Kristoffersen 1991). The slope of the Crary Fan reaches $4^{\circ}$ in the upper part and decreases towards the basin.

The continental slope off Coats Land is intersected by numerous gullies, channels, and small canyons. On the eastern side of Crary Fan, adjacent to the southwestern parts of Coats Land, a $70 \mathrm{~km}$ wide NE-inclined terrace dissected by several channels is developed in $2000 \mathrm{~m}$ to $3000 \mathrm{~m}$ water depth (Weber et al. 1994). The channels are flanked by associated ridges on their northwestern sides and merge to a major channel draining to the northeast below $3000 \mathrm{~m}$ water depth. Two other channel systems drain the central and western part of the Crary Fan to the north and northeast (Fig. 2). Multichannel seismic investigations showed that the channels become younger from west to east, and that they tend to migrate eastward (Kuvaas \& Kristoffersen 1991). The easternmost channel shows a V-shaped cross section in its proximal part, changing to a broad, flat cross section in the distal part. For description of features related to these channels they numbered the channel-levee systems from west to east (Channellevee System I to III, Fig. 2).

\section{Stratigraphic context}

Sedimentation rates in the southeastern Weddell Sea can be estimated for the Neogene from the results of Ocean Drilling Program (ODP) Site 693, which is located on a continental midslope bench off Dronning Maud coast, $10 \mathrm{~km}$ from the margin of the Wegener Canyon, in a water depth of $2359 \mathrm{~m}$ (Fig. 2). Late Miocene sedimentation rates were $c .24 \mathrm{~m} \mathrm{Ma}^{-1}$ and increased to $60 \mathrm{~m} \mathrm{Ma}^{-1}$ in the early Pliocene; Quaternary sedimentation rates were $16 \mathrm{~m} \mathrm{Ma}^{-1}$ (Gersonde et al. 1990). The Pleistocene sedimentation rate for the last $\sim 1 \mathrm{Ma}$ is $10 \mathrm{~m} \mathrm{Ma}^{-1}$ (Grobe et al. $1990 \mathrm{~b}$ ).

Due to a lack of a continuous carbonate content in cores from the southeastern Weddell Sea, sediments cannot be dated using ${ }^{18} \mathrm{O}$ stratigraphy. The likely presence of sediment reworking complicates the use of ${ }^{14} \mathrm{C}$ dating of organic carbon to obtain a stratigraphy for sediment cores. To overcome these difficulties a lithostratigraphy was developed by stacking of sedimentological parameters of 11 cores from the continental slope off Dronning Maud Land (Grobe \& Mackensen 1992). The stacks can be correlated with the continuous $\delta^{18} \mathrm{O}$ records of planktic and benthic foraminifera in core PS1506 (Latitude $68.728^{\circ} \mathrm{S}$, Longitude $5.823^{\circ} \mathrm{W}$ ) in the eastern Weddell Sea for the last $300 \mathrm{ka}$ 


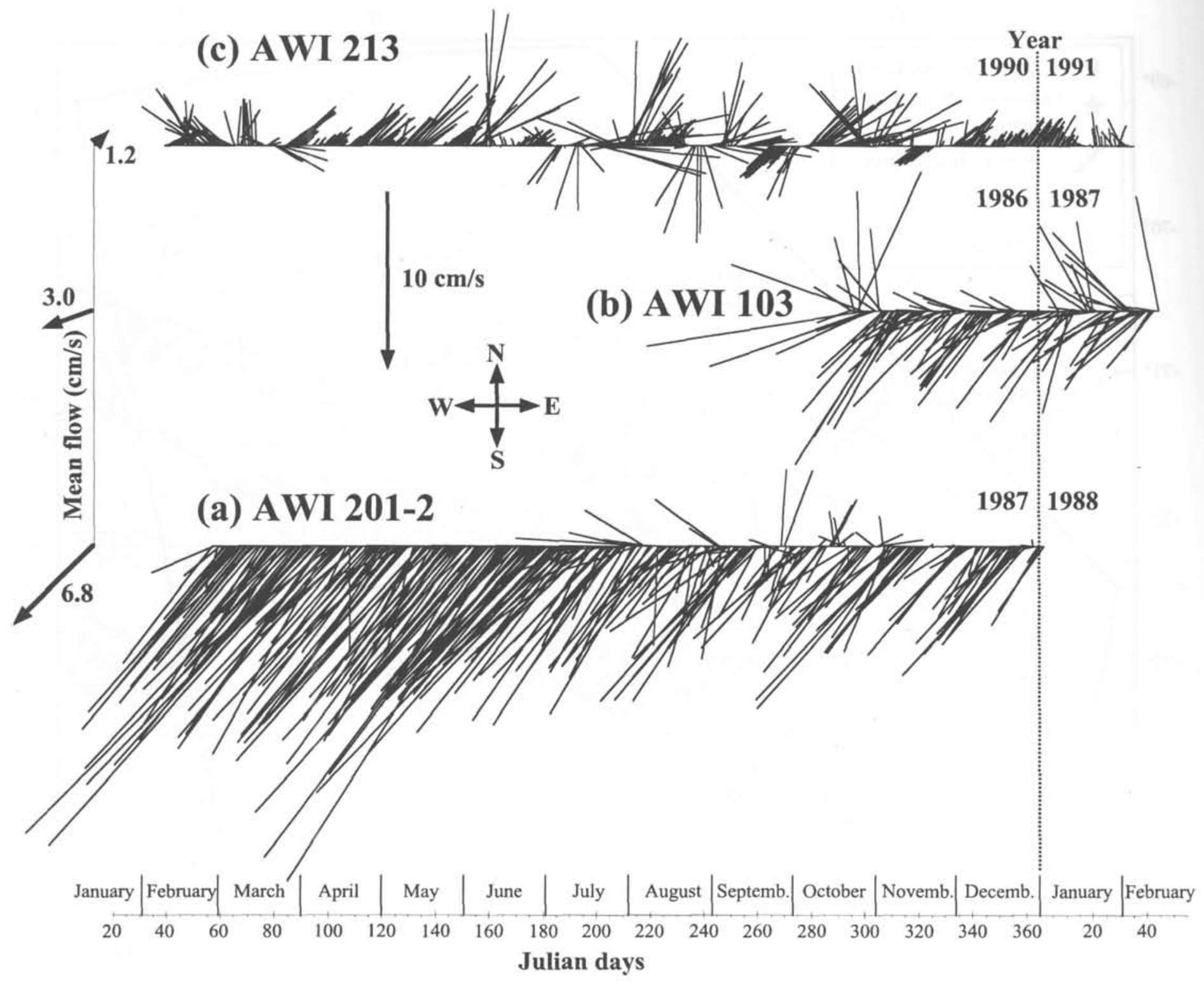

Fig. 3. Stick plot diagrams of the time series of daily mean current speeds from instruments deployed in moorings off Coats and Dronning Maud Land for up to one year (for location of moorings see Fig. 2). (a) record from mooring AWI 201-2 on the continental shelf off Vestkapp in $461 \mathrm{~m}$ water depth from February 27, 1987 to January 3,1988 (G. Rohardt, unpublished data). The current meter was located in $380 \mathrm{~m}$ of water depth. (b) record from mooring AWI 103, deployed in $3415 \mathrm{~m}$ water depth at the continental slope off Vestkapp from October 23, 1986 to February 17,1987 (modified from Fahrbach et al. 1992). The current meter was located $4 \mathrm{~m}$ above the seafloor. (c) record from mooring AWI 213, deployed in $4440 \mathrm{~m}$ water depth in a distal channel originating on the eastern Crary Fan, from February 8, 1990 to February 6, 1991 (modified from Rohardt et al. 1992). The current meter was located $10 \mathrm{~m}$ above the sea floor. Data extracted from the Ocean Circulation Database that can be accessed at www.awi-bremerhaven.de/OZE/ocdb/database.html.

(Mackensen et al. 1994) and allow a detailed interpretation of the environmental changes during this period. One of the conditions for the use of this lithostratigraphy, however, is the availability of high-resolution data for the carbonate content, grain size distribution, clay mineralogy, and siliceous microfossil content. The results of this lithostratigraphic approach indicate decreasing mean sedimentation rates with increasing water depth on a profile across the continental slope in the eastern Weddell Sea for hemipelagic sediments during a climatic cycle, with mean values of $5.2 \mathrm{~cm} \mathrm{ka}^{-1}$ for the upper and $1.3 \mathrm{~cm} \mathrm{ka}^{-1}$ for the lower slope (Grobe et al. 1990a). The rates can increase up to $25 \mathrm{~cm} \mathrm{ka}^{-1}$ close to the shelf in the beginning of each interglacial, whereas lowest values around $0.6 \mathrm{~cm} \mathrm{ka}^{-1}$ are found during glacials in the basin.

On the eastern Crary Fan, an area which is strongly influenced by contour currents of the Weddell Gyre, glacial sedimentation rates reach values up to $376 \mathrm{~cm} \mathrm{ka}^{-1}$ (core PS1789 in Fig. 2, water depth is $2411 \mathrm{~m}$ ). The rates decrease with increasing water depth and distance from the shelf edge to $125 \mathrm{~cm} \mathrm{ka}^{-1}$ in core PS1599 and $60 \mathrm{~cm} \mathrm{ka}^{-1}$ in core PS1790 (Fig. 2; Weber et al. 1994). On the western Crary Fan, where sediment-acoustic data show debrisflow deposits and slumps, sedimentation rates are in the range of $8 \mathrm{~cm} \mathrm{ka}^{-1}$ for near-surface sediments in a water depth of $2934 \mathrm{~m}$ (cores PS1606); the sedimentation rate decreases to $2 \mathrm{~cm} \mathrm{ka}^{-1}$ in shallower water depth (1612 m, core PS1607; Melles 1991).

\section{Seismic characteristics: reflection profiles}

Five profiles, which show different features of the shape and internal architecture of contourite-influenced sediment bodies, have been chosen for presentation here (Fig. 4a, c-e). These profiles are complemented by a succession of 5 Parasôund profiles across Channel-Levee Complex III on the eastern Crary Fan (Fig. 4b, for location of seismic and Parasound profiles see Fig. 2). A seismic stratigraphy has been developed by Miller et al. (1990) on the basis of the results from ODP Site 693 (Leg 113, Barker et al. 

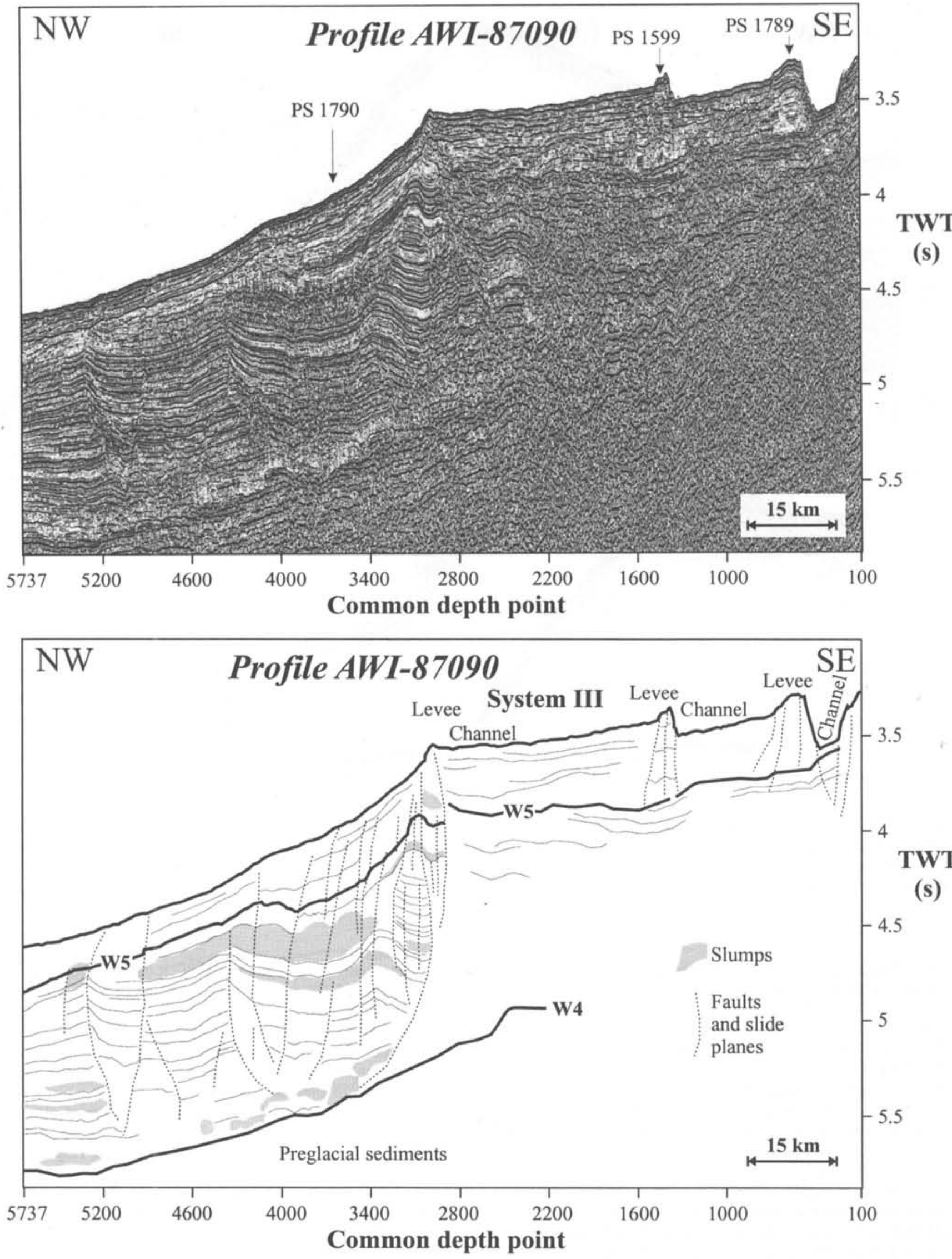

Fig. 4. (a) Multichannel seismic profile AWI-87090 across the eastern Crary Fan (modified from Oszkó 1997; for location of the profile see Fig. 2), with core locations indicated above profile. Sediments above unconformity W4 represent the Cenozoic glaciomarine sequence in the Weddell Sea (Miller et al. 1990). The sediment sequence in the northwestern part of the profile shows many faults, growth faults and listric shear planes, associated with slumped blocks and slides (gray shaded). In the southeastern part of the profile three channel-levee systems can be seen, two of them with well-developed levees, which show indication of overloading as a result of very high sedimentation rates. Indeed, sedimentation rates of $125 \mathrm{~cm} \mathrm{ka}^{-1}$ and more than $200 \mathrm{~cm} \mathrm{ka}^{-1}$ have been measured for last glacial sediments in cores PS1599 and PS1789, respectively (Weber et al. 1994). The sequence above unconformity W5 represents upper Miocene to Recent sediments deposited under an increased influence of contour currents (Miller et al. 1990). 


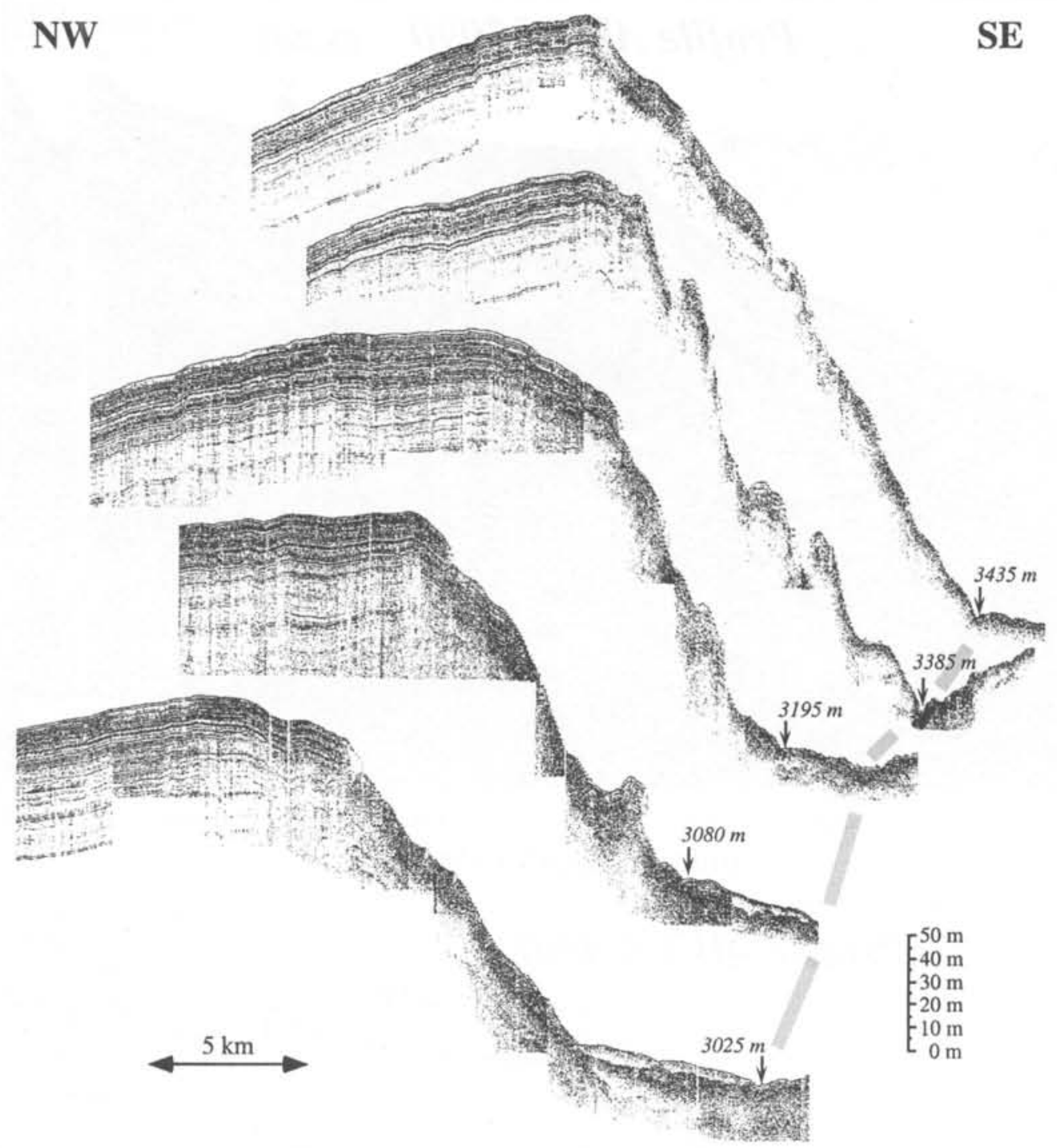

Fig. 4. (b) Succession of five Parasound profiles from the levee crest into the adjacent channel in water depths of $c .3000$ to $3450 \mathrm{~m}$ of Channel-Levee System III (modified from Kuhn \& Weber 1993; for location of the profiles see Fig. 2). Deep penetration and parallel reflectors characterize the levee deposits, thus indicating high sedimentation rates. Channel deposits show a rough topography, prolonged reflectors and some slides, which is typical for coarse sediments and erosive conditions.

1988, 1990). The description of the profiles shown in Figs 4a and c-e is based on this stratigraphy, which has been refined and applied to numerous other seismic profiles in the southeastern Weddell Sea by Kuvaas \& Kristoffersen (1991), Moons et al. (1992), Oszkó (1997), and Bart et al. (1999).

Profile AWI-87090 crosses the eastern Crary Fan from northwest to southeast (Oszkó 1997). In the southeast the profile shows two well-developed channel-levee systems, where the levees form narrow ridges which overtop the adjacent seaward slope (Fig. 4a). A sequence with a thickness of $c .0 .5 \mathrm{~s}$ two-way travel time (TWT) under these ridges is separated from the ambient sediment by faults, forming a wedge-shaped sediment ridge. Sediment overloading as a result of very high sedimentation rates is thought to cause subsidence of these ridges, and suggests very high sedimentation rates on the ridges. Sedimentation rates of 125 to $250 \mathrm{~cm} \mathrm{ka}^{-1}$ and $>200 \mathrm{~cm} \mathrm{ka}^{-1}$ have been determined for the period of the last glacial maximum at core locations PS1599 and PS1789 on the two ridges, respectively (Weber et al. 1994). The northwestern part of the profile is characterized by the presence of numerous large, synsedimentary, listric shear planes and faults, some of them developed as growth faults, associated with a number of slump blocks and slides. The slope inclination increases significantly seaward of the location where the first deep fault occurs. The faults end at the prominent reflector W4 in more than 1 s TWT sediment depth. W4 represents the base of the Cenozoic glaciomarine sequence in the Weddell Sea (Miller et al. 1990). The susceptibility of the sediment to failure can be seen as an indicator for high sedimentation rates in combination with a high pore water pressure.

A succession of five Parasound profiles (from Kuhn \& Weber 1993) in the downward course of Channel-Levee System III is depicted in Figure 4b. The sediments on the ridge allow deep acoustic penetration and the reflection pattern consists of numerous parallel to subparallel reflectors. The crest of the levee is not bounded by faults, as observed in the proximal region of the Channel III in Profile AWI-87090, so that the reflectors of the levee are undisturbed. The channel bottom and slope show a rough topography with some slide deposits. Prolonged reflectors indicate coarse sediment and an erosive regime. Profile AWI92020 (Fig. 4c; Oszkó 1997) crosses the Channel-Levee System II on the central Crary Fan in a water depth of $c .4000 \mathrm{~m}$. Above a coarse layer of channel deposits two asymmetric levees (the levee of System II and the old eastern levee) developed along Channel II. Another channel (labeled old channel) developed southeast of 

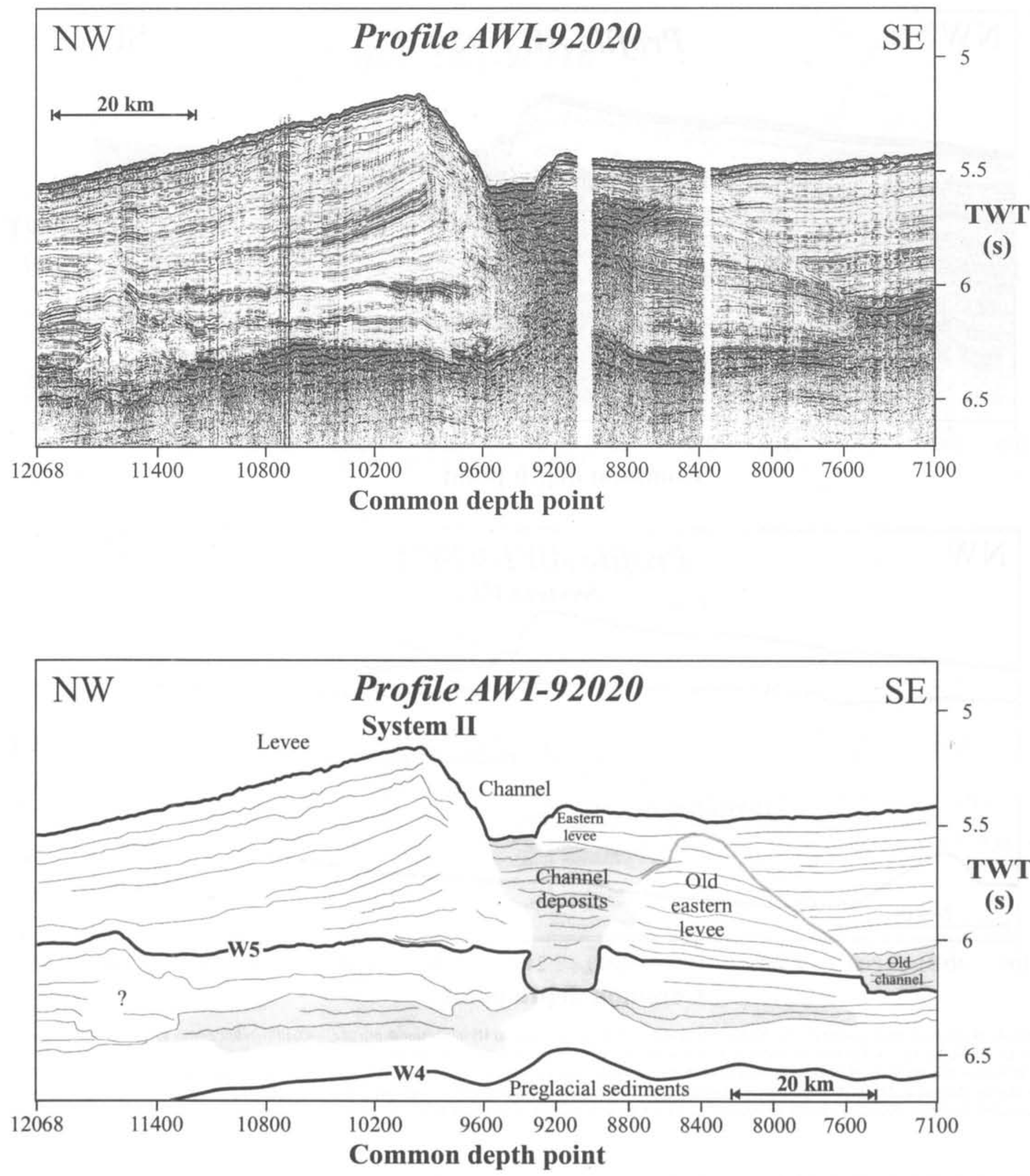

Fig. 4. (c) Multichannel seismic profile AWI-92020 across Channel-Levee System II in a water depth of c. $4000 \mathrm{~m}$ (modified from Oszkó 1997; for location of the profile see Fig. 2). A very well-developed northwestern levee can be seen, showing low-amplitude, highly continuous, thin layered reflectors. The southeastern side of the channel shows only a very small levee, merging into parallel-bedded sediment southeast of it. The subsurface structures indicate that a larger southeastern levee (labeled old eastern levee) was present earlier, but has been buried. Note that position of unconformity W5 is tentative. However, this reflector marks the bases of wedge-shaped channel levees, and thus correlates well with the idea of increased current influence for younger sediments. Coarse channel sediments are shaded grey. 

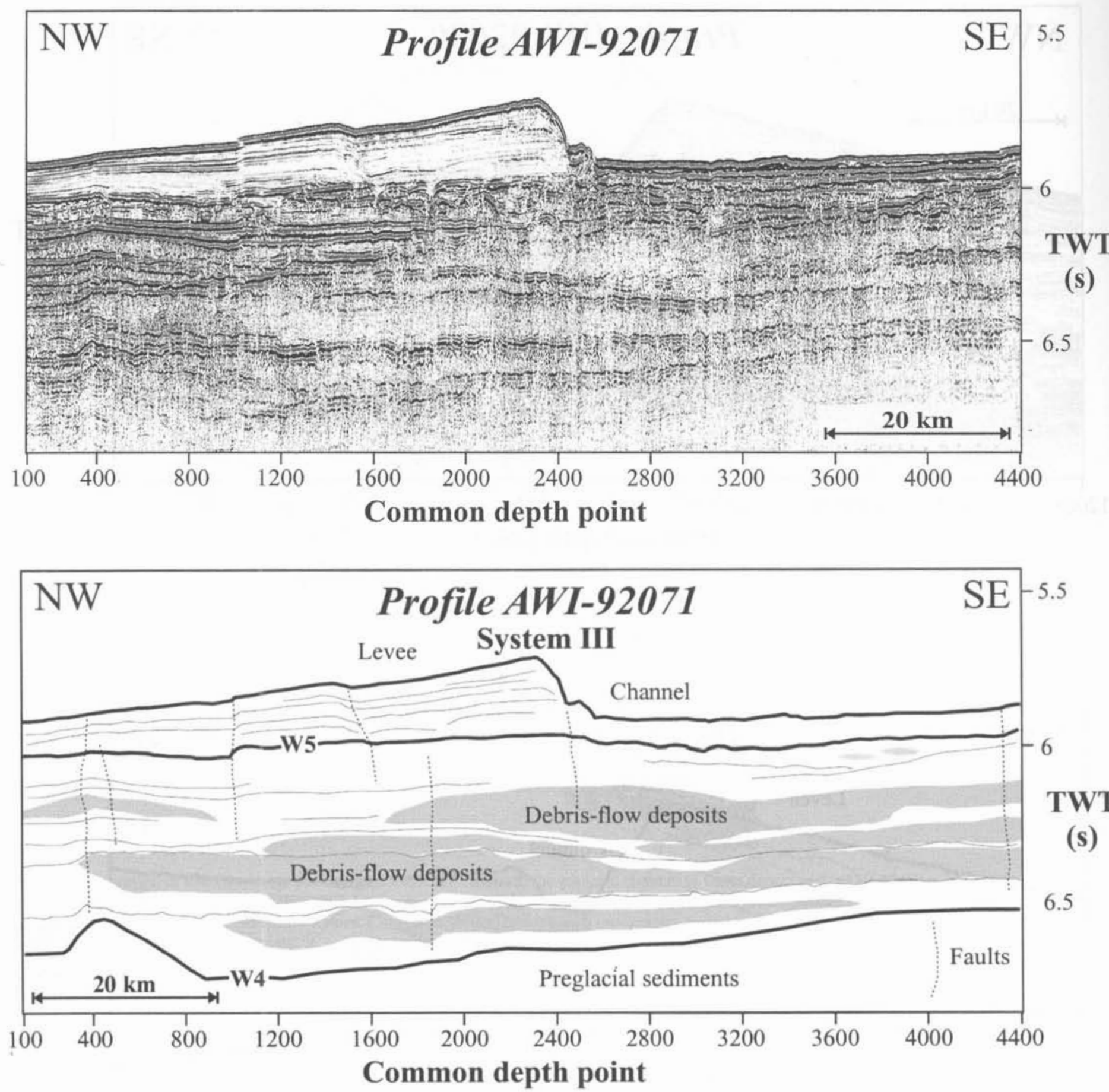

Fig. 4. (d) Multichannel seismic profile AWI-92071 across Channel-Levee System III in a water depth of $c .4400 \mathrm{~m}$ (modified from Oszkó 1997 ; for location of the profile see Fig. 2). The levee formed above unconformity W5 as a well-developed wedge-shaped sediment unit, showing low-amplitude, highly continuous, thin layered reflectors. The associated channel is broad and flat with very high-amplitude continuous reflectors. Beneath this a sediment sequence charaterized by high-amplitude, moderately continuous reflectors, mixed with acoustically transparent sections, which are thought to be debrisflow deposits (grey shaded), probably represents the early Cenozoic glaciomarine sedimentation.

the eastern levee, but both, old channel and old levee, were subsequently buried from the southeast, maybe by levee sediments of System III. The main channel decreased significantly in size and developed a smaller eastern levee. Bart et al. (1999) interpreted the coarse channel deposits between $c .6 .3$ and 6.5 TWT as a chaotic seismic facies resulting from large-volume mass wasting processes of sediments from the Crary Fan and the Dronning Maud Land slopes during the early Pliocene.

Profile AWI-92071 (Fig. 4d; Oszkó 1997) is located across Channel III in a water depth of c. $4400 \mathrm{~m}$. A levee-like feature developed as a narrow wedge of low-amplitude, continuous, thin- layered reflectors on top of a c. $0.6 \mathrm{~s}$ TWT thick sediment sequence characterized by sharp discontinuities and many debrisflow deposits and bounded by unconformities W4 and W5. The seafloor southeast of the wedge-shaped sediment body is very flat and shows highly reflective coarse sediments. There is no indication of an eastern channel restriction. Taking into account a northeasterly current direction (measured nearby in mooring AWI 213), the levee of System III may have developed as a drift body shaped by contourite currents. The transition between a more turbidite-influenced channel-bound levee system to a contourite-current shaped drift takes place between the positions of 

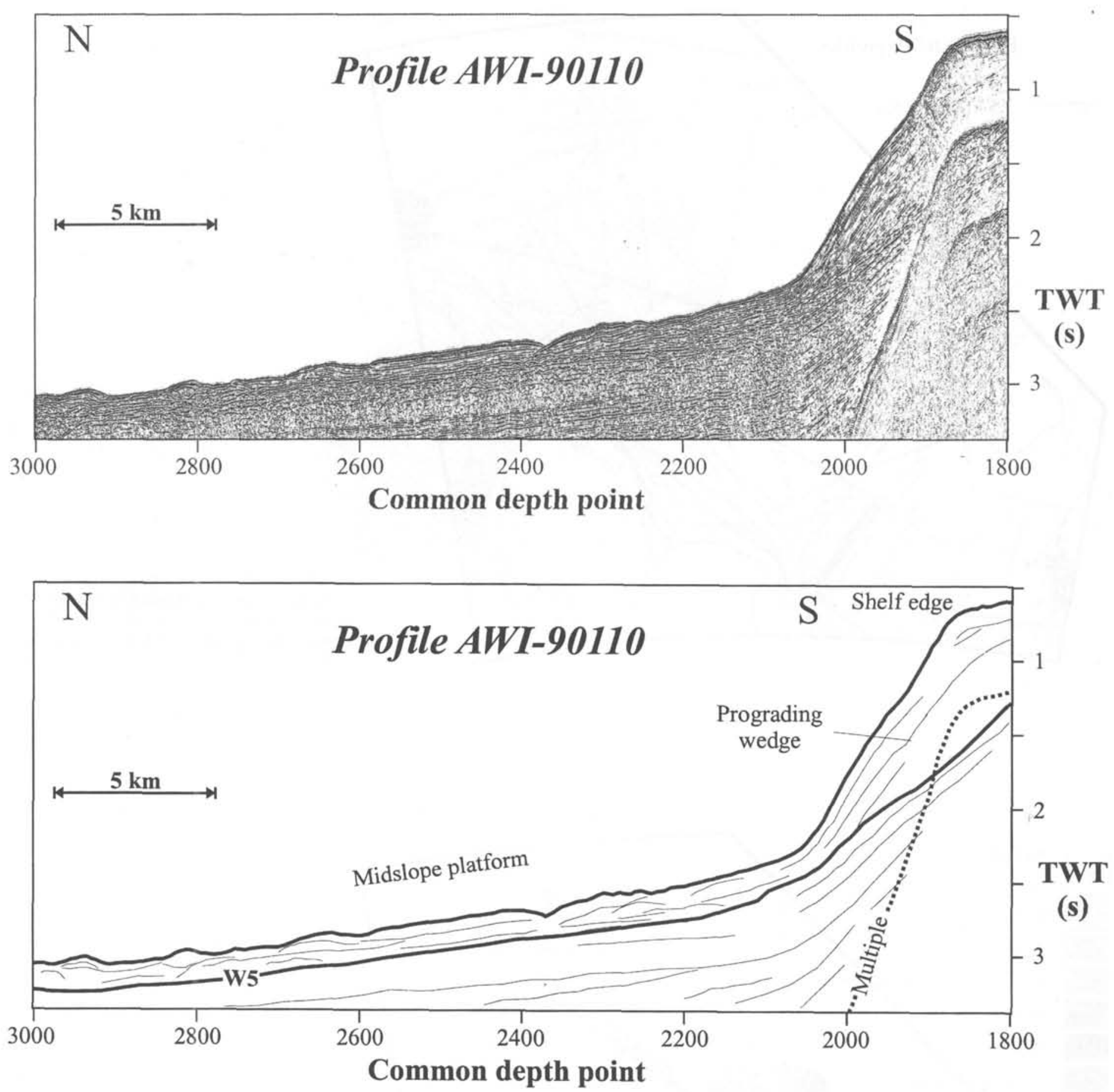

Fig. 4. (e) Multichannel seismic profile AWI-90110 across the upper midslope terrace, the upper continental slope and the shelf edge landward of the Wegener Canyon (modified from Oszkó 1997; for location of the profile see Fig. 2). The uppermost unit above unconformity W5 shows a rough undulating surface and high-amplitude, discontinuous reflectors, indicating relative small lens-shaped sediment bodies in the area of the midslope terrace. These merge landward into lower-amplitude, more continuous reflectors, representing the foreset beds of a prograding wedge.

the Parasound profiles and seismic profile AWI-92071, i.e. between 3000 and $4400 \mathrm{~m}$ of water depth.

Profile AWI-90110 (Fig. 4e; Oszkó 1997) crosses the upper midslope terrace and the upper continental slope and shelf edge off Dronning Maud Land at c. $14^{\circ} \mathrm{W}$. The upper part of the profile shows prograding foreset beds at the shelf edge. The midslope terrace shows a sediment sequence above unconformity W5 which is characterized by an irregular, undulating sediment surface and small lens-shaped sediment bodies, indicating strong current influence and residual sediments. These bodies merge into the foreset beds of the upper continental slope without any apparent unconformity. Very low sedimentation rates of less than $1 \mathrm{~cm} \mathrm{ka}{ }^{-1}$ for the last $4 \mathrm{Ma}$ in core PS1481, lying in $2452 \mathrm{~m}$ water depth in extension of Profile AWI-90110, confirm the formation of residual sediments (Grobe \& Mackensen 1992).

\section{Seismic characteristics: $3.5 \mathrm{kHz} /$ Parasound mapping}

In the southeastern Weddell Sea, in an area between $14^{\circ}$ and $36^{\circ} \mathrm{W}$ and $69.5^{\circ}$ and $75^{\circ} \mathrm{S}$, we mapped the penetration depths (Fig. $5 \mathrm{~b}$ ) and echosounder facies types (Fig. 5c) using $3.5 \mathrm{kHz}$ and 

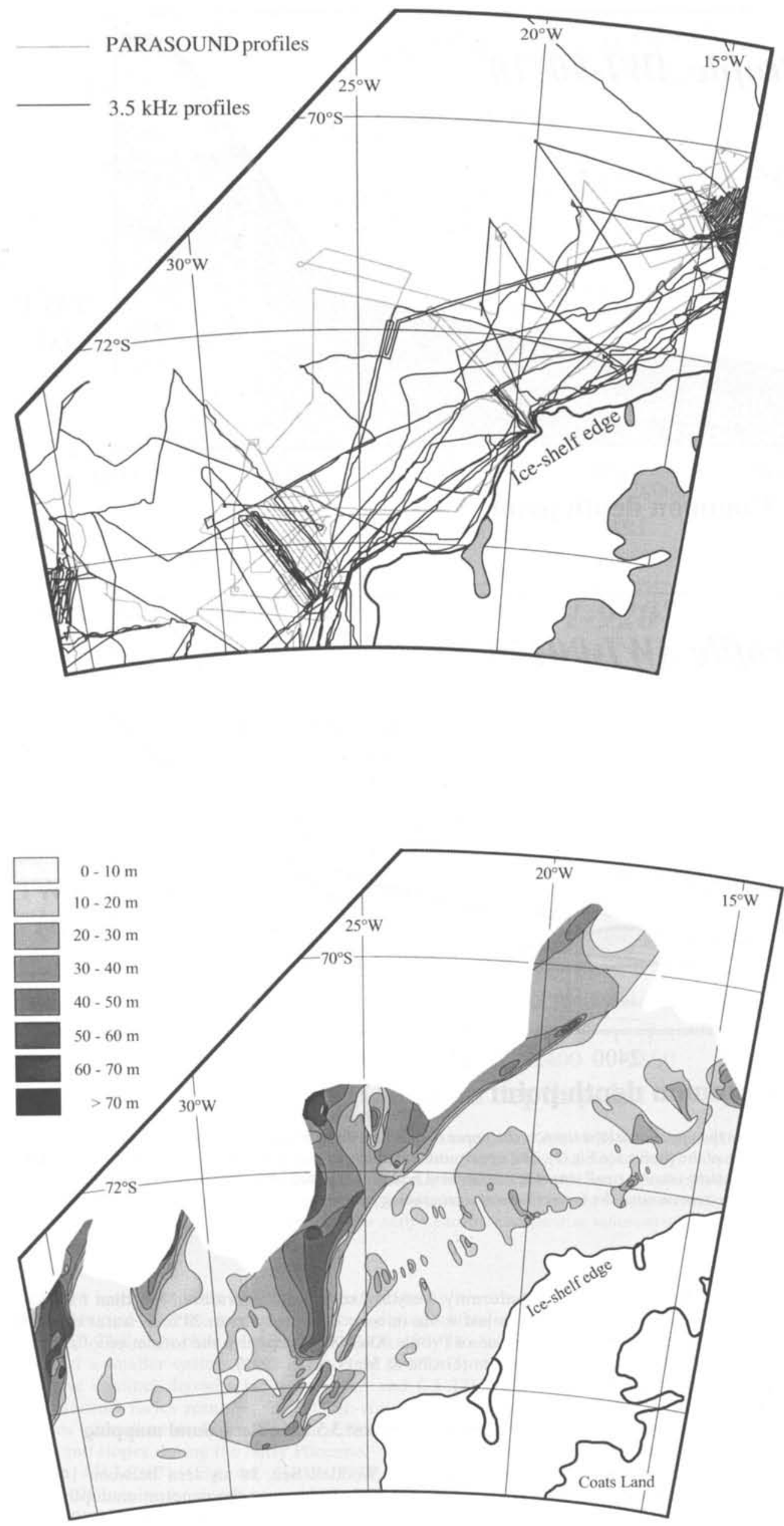

Fig. 5. (a) $3.5 \mathrm{kHz}$ and Parasound profile grid in the southeastern Weddell Sea, on which the acoustic penetration and echo-type character maps (Figs 5 b \& c) are based (from Kuhn et al. 1995).
Fig. 5. (b) Acoustic penetration of a $3.5 \mathrm{kHz}$ signal in the southeastern Weddell Sea, based on a p-wave velocity of $1500 \mathrm{~m} \mathrm{~s}^{-1}$ (from Kuhn et al. 1995). High penetration depths indicate high sedimentation rates and finegrained sediments. 


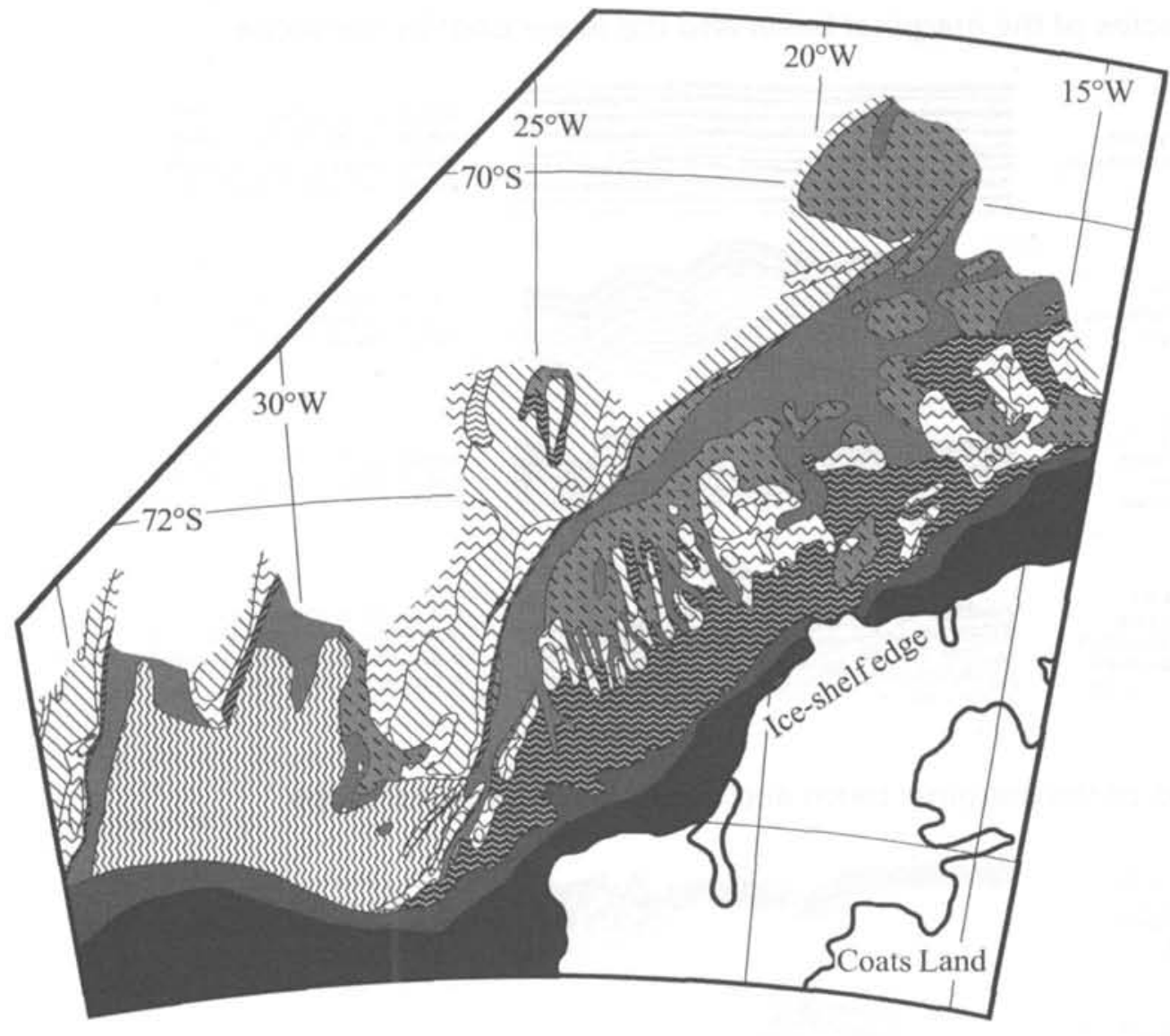

Fig. 5. (c) Classification of the echo-type character of surface sediments in the southeastern Weddell Sea. A key to the patterns, a description and an example of their associated echo types, and an interpretation is given in Figure 5d (compiled from Kuhn et al. 1995; Kuhn \& Weber 1993; Melles \& Kuhn 1993).
Parasound systems. The maps are a compilation of results from Kuhn \& Weber (1993) and Melles \& Kuhn (1993), extended by data from the Coats and Dronning Maud Land continental shelf. slope and adjacent deep-sea areas. Ten different facies patterns could be distinguished and related to certain sedimentary processes and structures (Fig. 5d). The maps are based on a dense grid of $3.5 \mathrm{kHz}$ and Parasound profiles (Fig. 5a). Penetration depth generally is a function of the physical properties of a sediment. For the southeastern Weddell Sea, where terrigenous particles dominate sediment composition, the penetration depth can mainly be attributed to a combination of grain size and water content of the sediment. The grain size is controlled by the glacialmarine transport processes, which can be inferred from the echosounder profiles, whereas the water content is mainly affected by sedimentation rate. The distribution of facies types and penetration depths shows a very clear relation to the channel systems on the Crary Fan and along the continental slope off Coats and Dronning Maud Land. The channels themselves appear as broad paths characterized by prolonged bottom reflectors and shallow penetration depths. On their left side (looking downstream) they are bound by a small band of channel slope facies followed by multi-layered or wavy multi-layered facies and deep acoustic penetration, which slowly decreases with distance from the channels. To the right of the channels penetration depth is generally low. The proximal Crary Fan is characterized by large areas of wedging sub-bottom reflectors and low penetration depths, indicating prevalence of debris-flow deposits.

\section{Sediments: seabed photographs}

Seabed photographs have been taken in the Weddell Sea during the cruises of USCGC Glacier and USNS Eltanin in the 1960s.
Hollister \& Elder (1969) inferred the direction and strength of bottom currents from sediment lineations and the deflection of organisms by currents on oriented photographs at three sites on the shelf next to Crary Trough. All three photographs showed abundant large benthic animals and strong current evidence. Current direction was to the northwest.

\section{Sediments: core description and facies}

The surface sediments on the continental shelf in the southeastern Weddell Sea are dominated by poorly-sorted, coarse residual deposits; finer particles generally are kept in suspension in the turbulent water conditions and are carried away by the Antarctic Coastal Current (Elverhøi \& Roaldset 1983). Biogenic particles are an integral part of the glaciomarine deposits. The upper continental slope down to a water depth of $c .1600 \mathrm{~m}$ shows also residual sediments with a sand content of more than $40 \%$ (Grobe \& Mackensen 1992). Silt and clay is winnowed away by contour currents and transported southwest along the continental slope. With increasing water depth, on the mid and lower slope, the mud content increases until it dominates the sediment. Its grain-size distribution pattern is the result of marine sorting processes acting on a glacially derived, poorly sorted debris (Fütterer \& Melles 1990; Melles 1991). Debris-flow deposits are described from the mid and lower slope (Anderson et al. 1979; Kuhn \& Weber 1993; Oszkó 1997). Clay mineral and heavy mineral assemblages in surface sediments from the Weddell Sea generally reflect the influences of the oceanographic and climatic regimes, the sediment sources and transportation processes (Ehrmann et al. 1992; Petschick et al. 1996; Diekmann \& Kuhn 1999; Diekmann et al. 1999).

Highest sedimentation rates are postulated for the transitions 


\section{Laminated/stratified facies of the marginal basin and the lower continental slope}

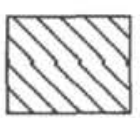

("multi-Layers")

several sharp continuous parallel

subbottom reflectors, high penetration

$(30-80 \mathrm{~m})$

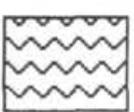

("multi-Layers wavy")

several sharp continuous to

discontinuous subbottom reflectors,

wavy, migrating layers, high

penetration ( $>30 \mathrm{~m}$ )

("semi-Prolonged Layers")

semiprolonged reflectors, some

continuous to discontinuous

subbottom reflectors, moderate

penetration $(10-30 \mathrm{~m})$

("multi-Layers discontinuous") several sharp discontinuous subbottom reflectors, hummocky pattern, some diffraction hyperbolae, moderate to high penetration $(20.40 \mathrm{~m})$

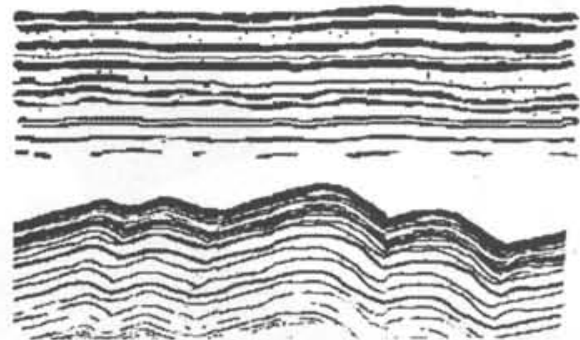

Undisturbed sequence of laminated fine-grained sediments deposited on channel levees mainly by contourite currents, high sedimentation rate

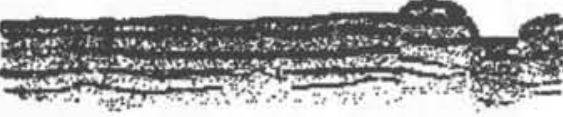

Medium-grained sediments, moderate sedimentation rates, in some places erosion

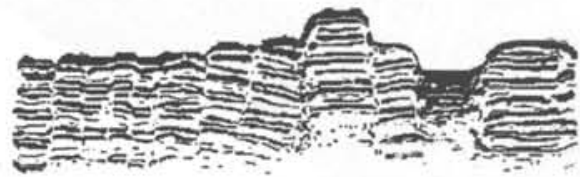

Fine-grained sediments, deposits disturbed by synsedimentary tectonics or by subbottom topography, moderate to high sedimentation rate

\section{Channel facies of the marginal basin and the lower continental slope}

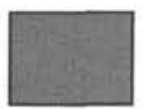

("Prolonged bottom")

strong and prolonged bottom reflector, low penetration $(<10 \mathrm{~m})$, no subbottom reflectors, low diffraction

hyperbolae (ampl, <40 m)

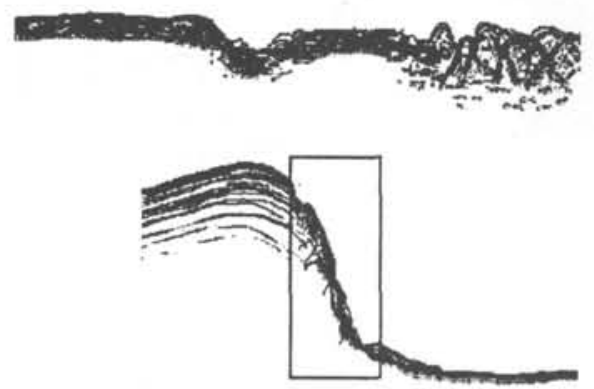

Coarse grained sediments in channeis and along the thalweg of turbidity and density currents, low sedimentation rate

("Diffraction hyperbolae , slope") steep eastward dipping slope with prolonged bottom echo and diffraction hyperbolae, low penetration (<10 m)

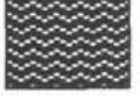

("Diffraction hyperbolae") large irregular partly overlapping hyperbolae with varying amplitudes. some with subbottom reflectors

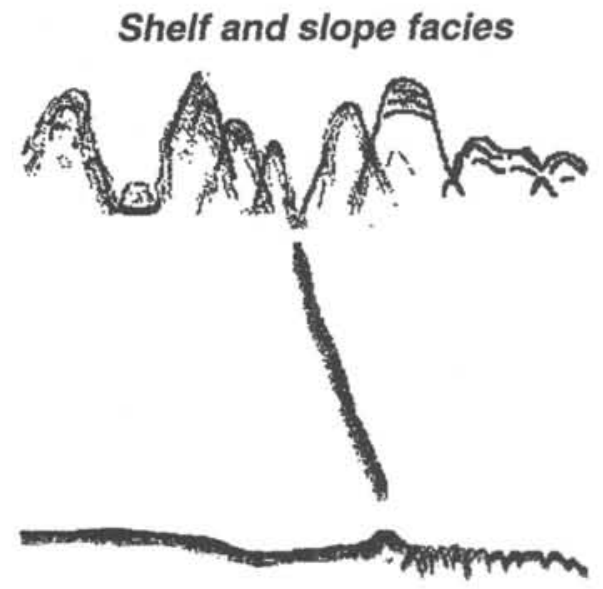

Rough topography (gullies, channels and ridges) in mid-slope areas of the continental slope

("Prolonged bottorn, shelf slope) steep shelf slope with prolonged bottom echo and few diffraction hyperbolae, low penetration (<10 m)

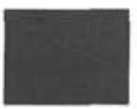

("Prolonged bottom, shelf) strong prolonged bottom echo on the shelf, with many smalldiffraction hyperbolae, partly rough bottom topography, low penetration $(<10 \mathrm{~m})$

Steep erosional slopes on the western side of channels on the lower slope and in the basin

("Wedging subbottoms") semi-prolonged reflectors, pillowtype layers, transparent pattern, wedging subbottoms, low penetration $(0.20 \mathrm{~m})$

Pattern

Description of echo type

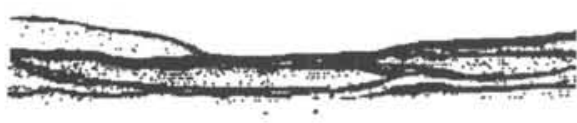

Example
Deposits of debris flows and stumps, high sediment input, coarse- to fine grained unsorted sediments, Crary Fan

Interpretation

Fig. 5. (d) Description of echo types used in Figure $5 \mathrm{c}$, examples for the echo types from $3.5 \mathrm{kHz}$ lines, and an interpretation regarding sedimentary processes (modified from Kuhn \& Weber 1993 and Kuhn et al. 1995). 
from glacial to interglacial conditions as a result of intensified ice rafting (Fütterer et al. 1988; Grobe \& Mackensen 1992), whereas Kuvaas \& Kristoffersen (1991) and Weber et al. (1994) propose highest sedimentation rates for the glacial periods when grounded ice extended to the shelf edge. The main topographical units along the southeastern Weddell Sea continental slope and adjacent areas have been sampled by cores. Detailed studies of the sedimentary environment and of sediment provenance have been carried out for the continental shelf (Anderson et al. 1980; Elverhøi \& Roaldset 1983), slope, and basin along Dronning Maud Land (Grobe \& Mackensen 1992), for Coats Land (Diekmann \& Kuhn 1997), the eastern Crary Fan (Weber 1992; Weber et al. 1994), and the middle and western Crary Fan (Melles 1991; Melles \& Kuhn 1993; Melles et al. 1995).

In compilation, four major lithofacies types can be distinguished: contourite-turbidite facies, hemipelagic facies, debrisflow facies, and shelf facies (Grobe \& Mackensen 1992; Weber et al. 1994; Diekmann \& Kuhn 1997). For a more detailed representation of the lithofacies types in different cores from the southeastern Weddell Sea, we split the contourite-turbidite facies into four subtypes: a fine-laminated facies, a coarse-laminated/stratified facies, and two transitional facies types to document the transition of the fine-laminated facies to the hemipelagic facies and the transition of the coarse-laminated/stratified facies to the hemipelagic facies.

\section{Contourite-turbidite facies}

The contourite-turbidite facies shows distinct layers of parallelbedded, in the case of coarser layers sometimes cross-bedded and/or graded, clayey, muddy, and sandy sediment. Lamination or stratification is in the sub-millimetre to centimetre range and bioturbation generally is absent. In fine-bedded laminae the clay content can be as high as $65 \%$. In contrast, cross-bedded layers almost entirely consist of coarse silt and sand. The facies was mainly deposited during glacials on the middle and lower slope and in the marginal basin. For the lithological column of the core figures (Fig. $6 \mathrm{a}-\mathrm{g}$ ) the contourite-turbidite facies has been split into a finelaminated facies and a coarse-laminated/stratified facies, to allow a more detailed lithological classification. The fine-laminated facies is well developed in cores PS1789, PS1599 and PS1790 on the upper Crary Fan. An example from core PS1790 is shown in Figure 6f. The coarser-laminated or stratified facies is also present in many parts of these cores. An example from a core taken in greater water depth (PS1635) can be seen in Figure 6d.

The contourite-turbidite facies originates in deposition from combined contour- and turbidity-current activity. The comparison of the coarse-laminated/stratified facies from a levee (e.g. in core PS1635, Fig. 6d) with the coarse-laminated/stratified facies in a channel (core PS1794, Fig. 6g) shows that they are very different, with the channel facies having a much higher sand content. This suggests that the levee sediments consist of the fines of turbidity current suspensions.

The configuration of pronounced sediment levees on the northwestern side of the channels indicate that overspill sedimentation from turbidity or density currents, triggered by the Coriolis force, plays an important role in the supply of sediment. In addition, the west- or southwestward directed vigorous contour currents entrain suspension from the turbidity currents and redeposit it downstream. A similar situation prevails on the western side of the Antarctic Peninsula (Rebesco et al. 1996, 1997), although there turbidity currents flow approximately perpendicular to contour currents, rather than in the opposite direction as here. The transitional facies from the fine laminated and the coarselaminated/stratified facies to the hemipelagic facies are probably of combined contourite-turbidite origin, but environmental conditions allowed for benthic activity, so that bioturbation occurred and the lamination is blurred.

\section{Hemipelagic facies}

The hemipelagic facies consists of bioturbated mud with a dominance of the fine fraction (clay contents c. 30 to $50 \%$ ), occasionally with increased proportions of ice-rafted debris (IRD). Part of the terrigenous sand fraction may contain biogenic opal. Generally strong to very strong bioturbation has blurred the primary sedimentary structures, although a faint stratification may be observed. The facies occurs during interglacials or during moderate interglacial to glacial conditions on the continental slope and in the marginal basin and often forms the surface sediments. An example of this facies in an X-radiograph section from core PS1789 can be seen in Figure 6e.

\section{Debris-flow facies}

The debris-flow or slump facies consists of a structureless mixture of coarse- and fine-grained sediments, which show no bioturbation. The facies mainly occurs in glacial intervals in the area of the central Crary Fan. Core 1607 from the western Crary Fan shows this facies under a $2 \mathrm{~m}$ thick surface layer of hemipelagic facies (Fig. 6c).

\section{Shelf facies}

Holocene shelf sediments comprise a high content of coarsegrained IRD, and a depletion of fine fraction, which is winnowed by the vigorous Antarctic Coastal Current. These residual sediments are underlain by overconsolidated diamictons, representing subglacial deposits from periods when the ice margin was located near the shelf edge. A good example of Holocene shelf facies is encountered in core PS1367 (Fig. 6a) from a water depth of $303 \mathrm{~m}$ on the shelf off Dronning Maud Land. This facies provides the source of the huge sediment masses that are removed from the shelf by ice sheets during glacial advances. They are released at the shelf edge where they initiate extensive turbiditycurrent activity in the channels of the continental slope.

A general predominance of the hemipelagic facies can be observed in many locations on the continental slope during interglacial stages, whereas the laminated facies prevails during glacials. However, conditions are variable along the continental slope in the southeastern Weddell Sea, and knowledge is insufficient so far about processes that are important especially for the formation of the glacial facies types, e.g. possible open water conditions during glacials.

\section{Sediment grain size: summary analytical results}

Granulometric differences offer the best critieria for the distinction of the lithofacies types. Silt- and clay-sized particles generally make up 80 to $90 \%$ of the contourite-turbidite facies, but significant differences exist for the silt-sized composition of the finelaminated and the coarse-laminated/stratified type. Fine-laminated sediments show a broad range of silt grain sizes with a maximum in the range of 6 to $7 \phi$, whereas coarse-laminated/stratified sediments generally have a peaked silt-size composition with a sharp maximum around $5 \phi$, which sometimes reaches into the sand-sized range (e.g. cores PS1599 and PS1635, Figs 6b, d). The IRD content can occasionally be high, especially for the finelaminated facies, but generally is low or absent.

Hemipelagic sediments show a uniformly distributed silt size fraction on the continental slope. In core PS1635 from the basin hemipelagic sediments show a maximum in the 7 to $8 \phi$ range, accompanied by an increased IRD content. This points to a depositional mechanism which is not dominated by currents.

The shelf facies shows high contents of gravel and sand, 


\section{PS1367}

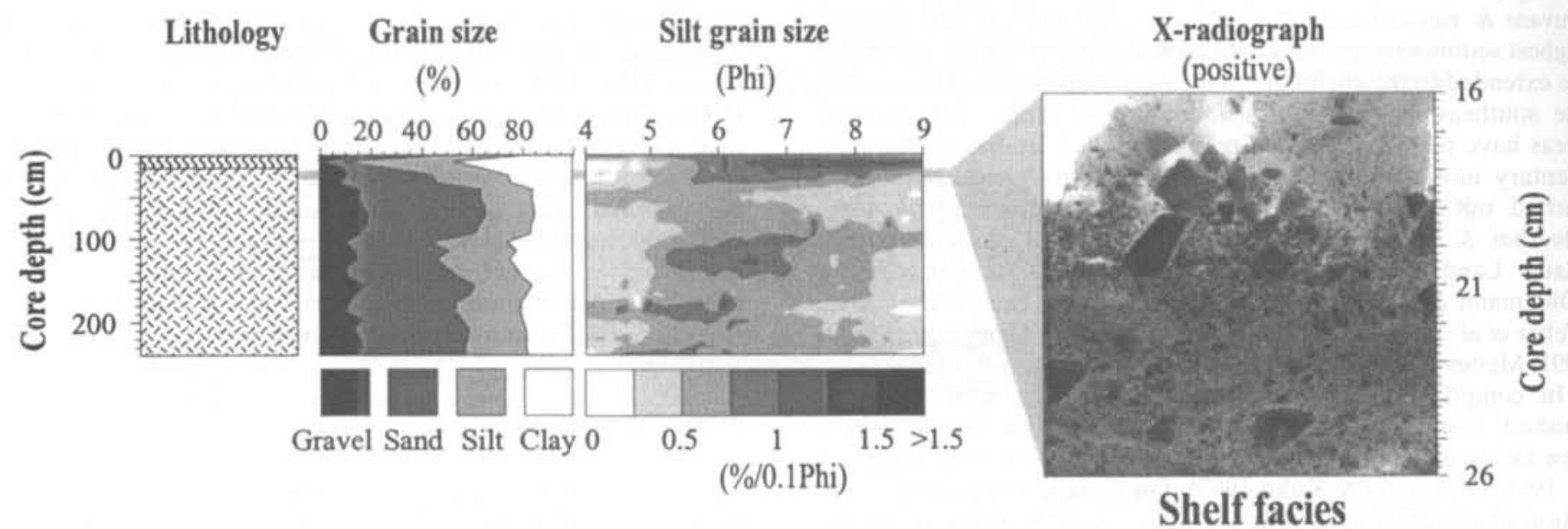

PS1599

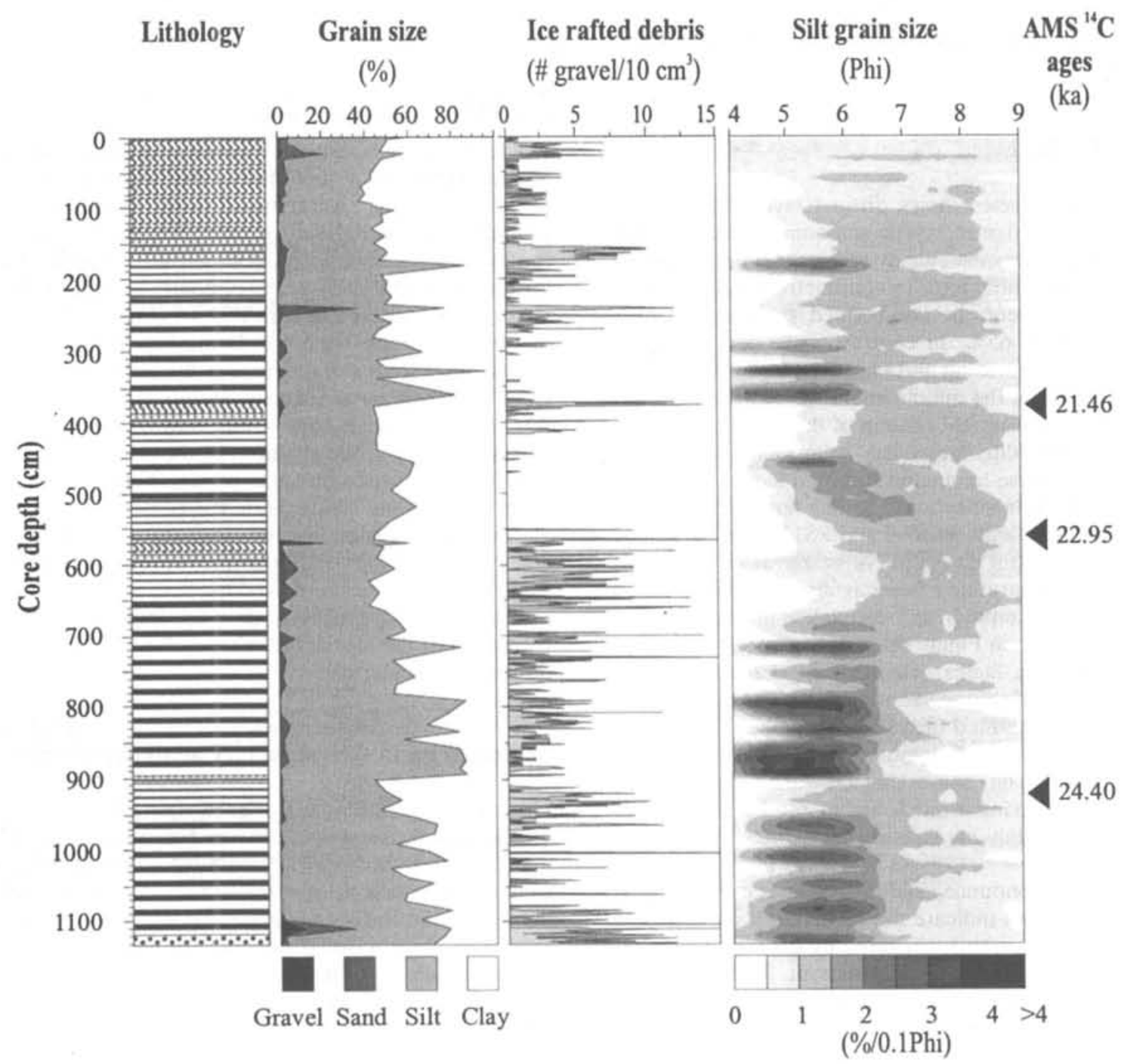

Fig. 6. Graphic logs of sediment cores PS1367 (a), PS1599 (b), PS1607 (c), PS1635 (d), PS1789 (e), PS1790 (f), and PS1794 (g). From left to right, the columns show: (i) lithology, classified into 7 different facies types (four major types; the contourite-turbidite facies is split up in four subtypes, (ii) the cumulative grain-size distribution of gravel, sand, silt, and clay versus sediment depth, (iii) the number of gravel-sized IRD particles per $10 \mathrm{~cm}^{3}$ versus core depth (no data available for PS1367). (iv) a contour diagram of the grain size distribution within the silt fraction versus sediment depth (no data available for PS1607 and PS1794). Ages of AMS ${ }^{14} \mathrm{C}$ dated sediment samples are shown for PS1599, PS1789, and PS1790. Age in PS1607 is based on $\delta^{18} \mathrm{O}$ curve. Age of $780 \mathrm{ka}$ in PS1635 corresponds to a magnetic reversal. X-radiographs of core sections typical of the different facies types are also shown. Note the different depth scale for PS1794 (data from Melles 1991; Weber 1992; Diekmann \& Kuhn 1997: Grobe unpublished data).

Sedimentological data and age models for all cores can be downloaded from the information system 'PANGAEA' under www.pangaea.de/PangaVista 


\section{PS1607}
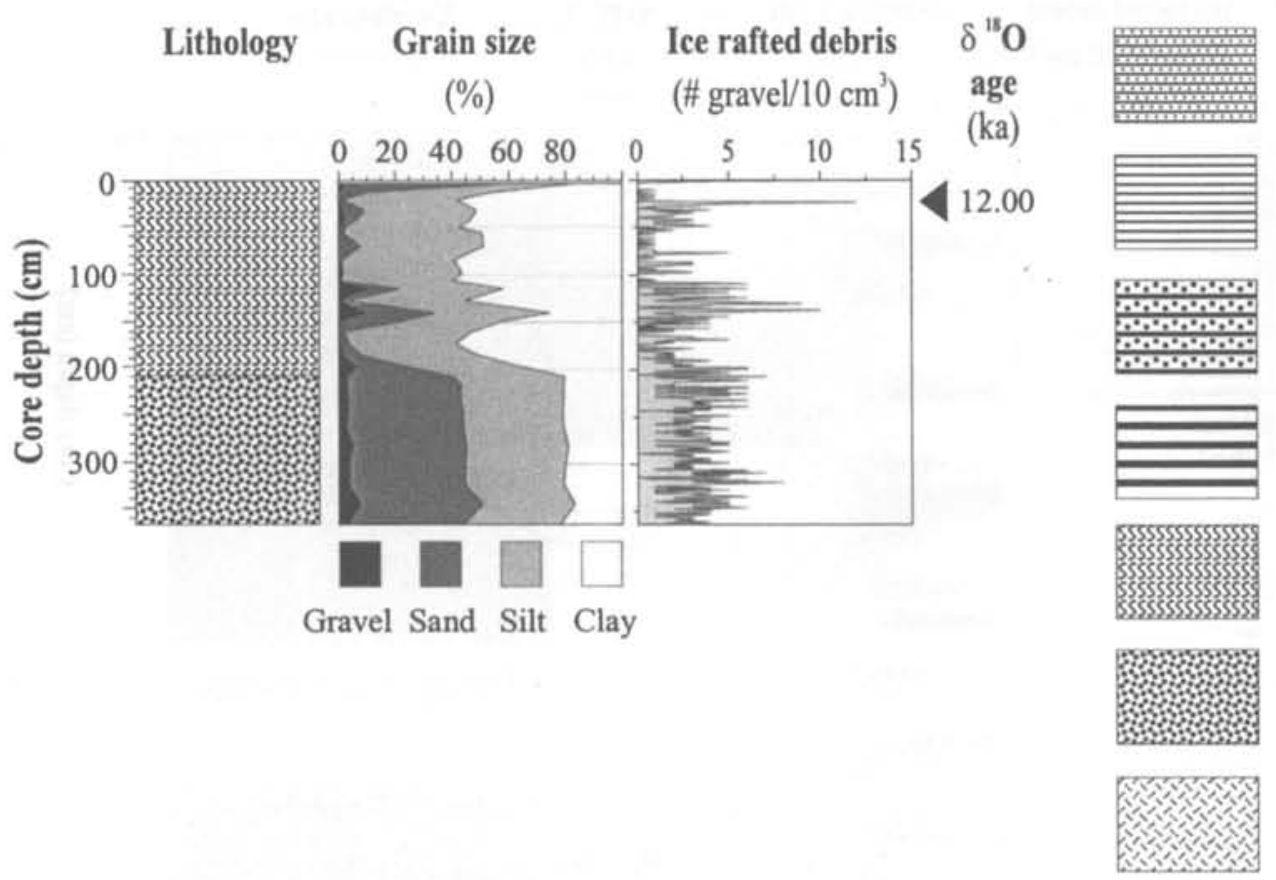

Transitional facies hemipelagic to finelaminated sediments

Fine-laminated facies

Transitional facies hemipelagic to coarselaminated sediments

Coarse-laminated/stratified facies

\section{Hemipelagic facies}

Debris-flow facies

\section{Shelf facies}

\section{PS1635}

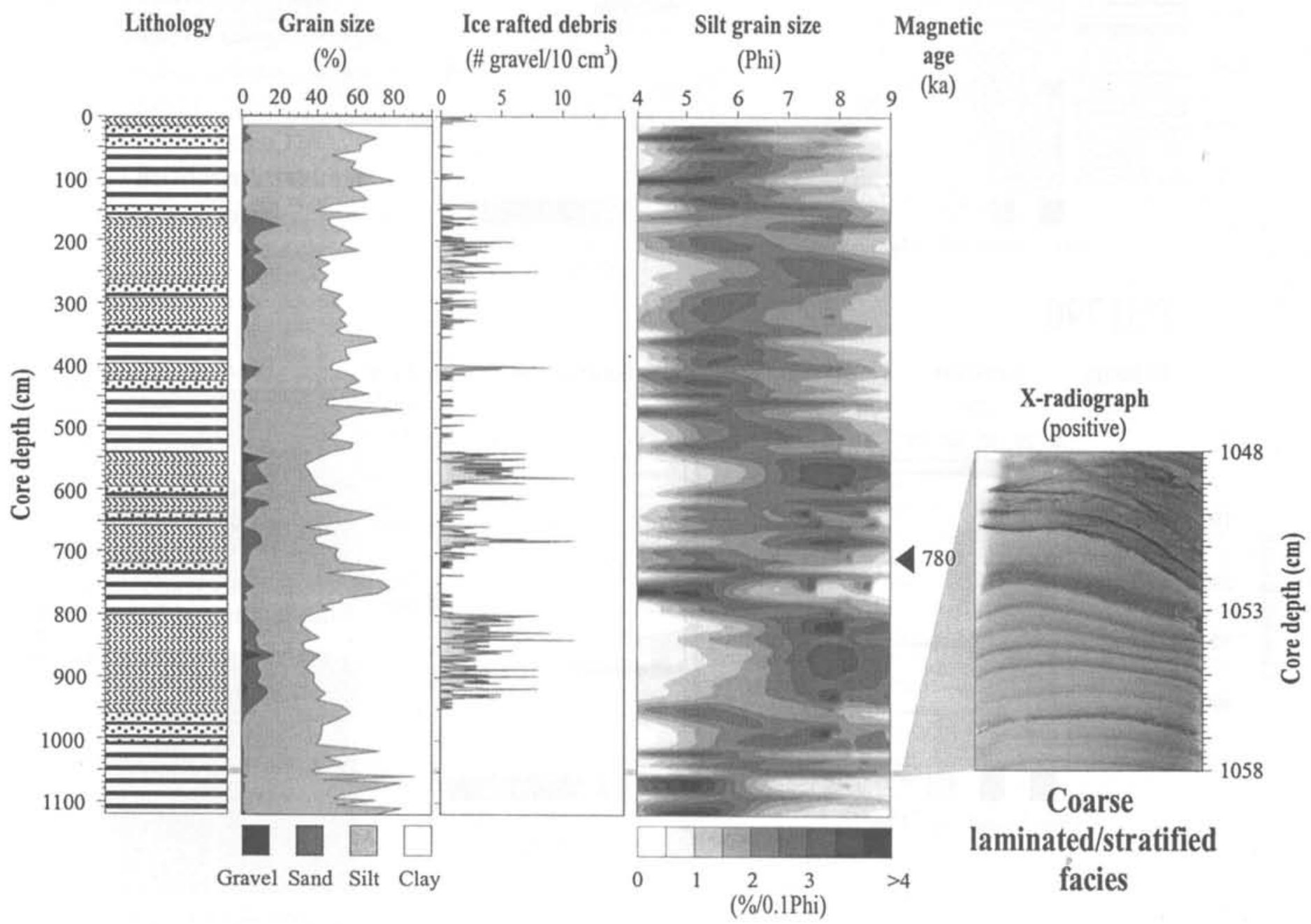

Fig. 6. PS1607 (c), PS1635 (d). 
PS1789

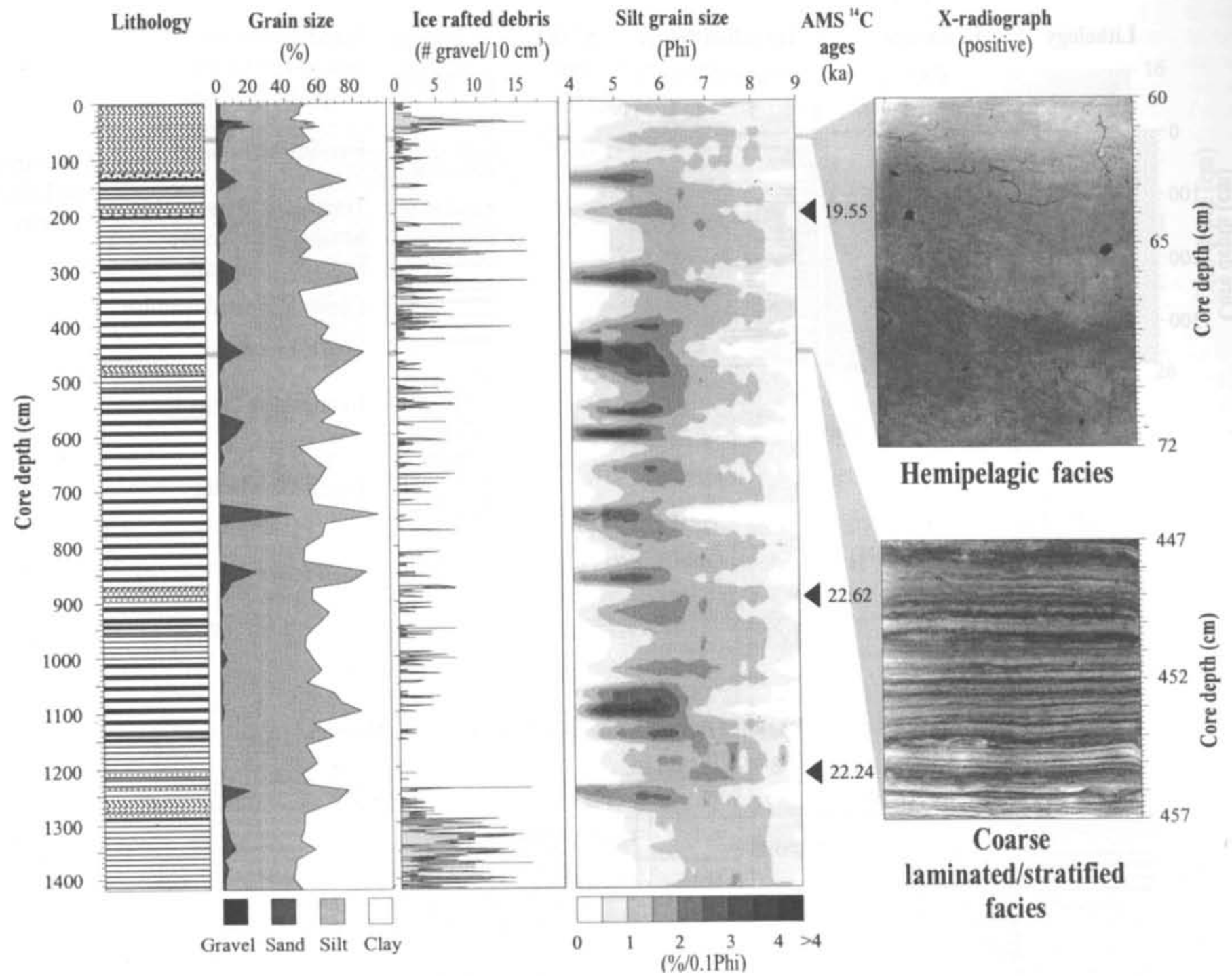

PS1790

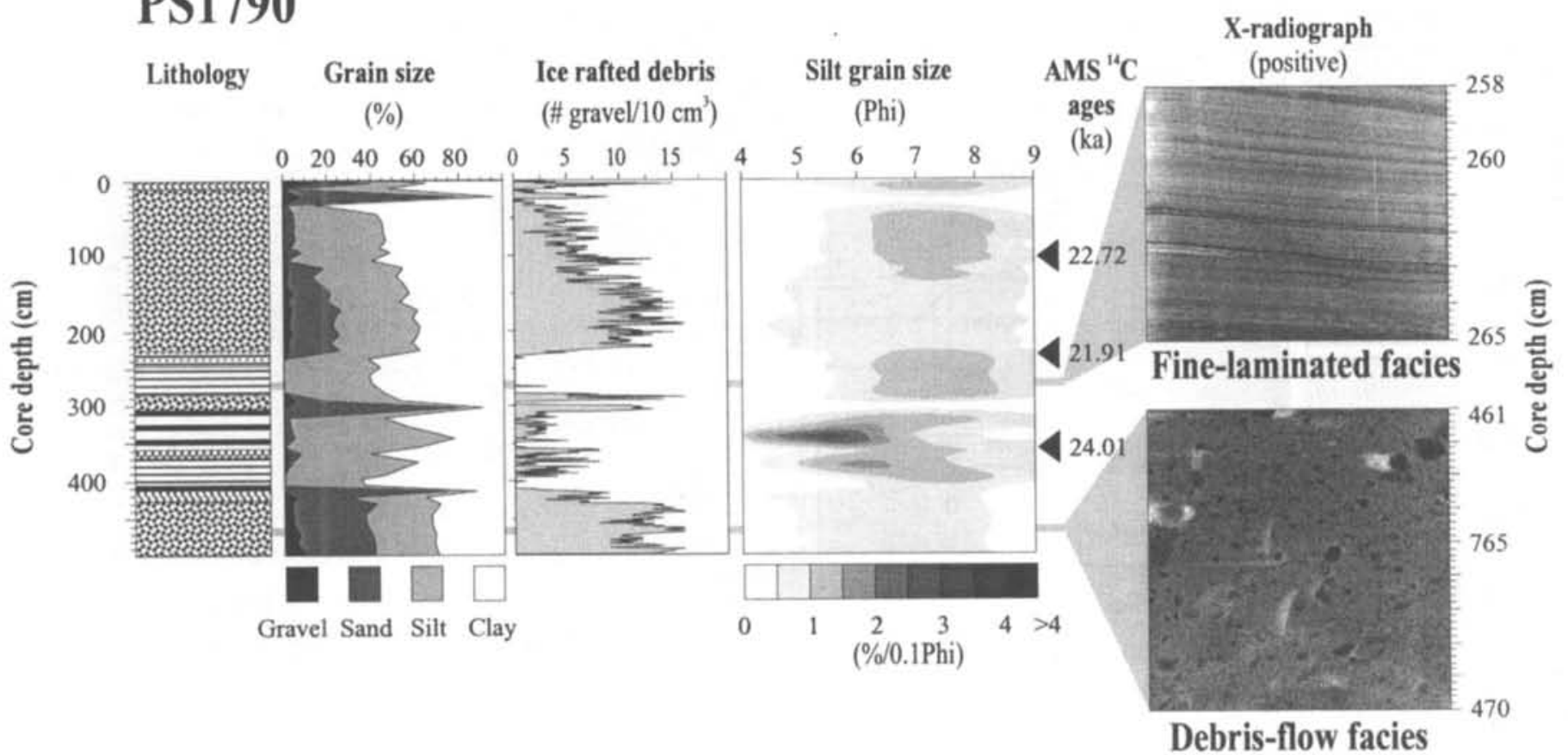

Fig. 6. PS1789 (e), PS1790 (f). 


\section{PS1794}

\section{Lithology Grain size}

(\%)

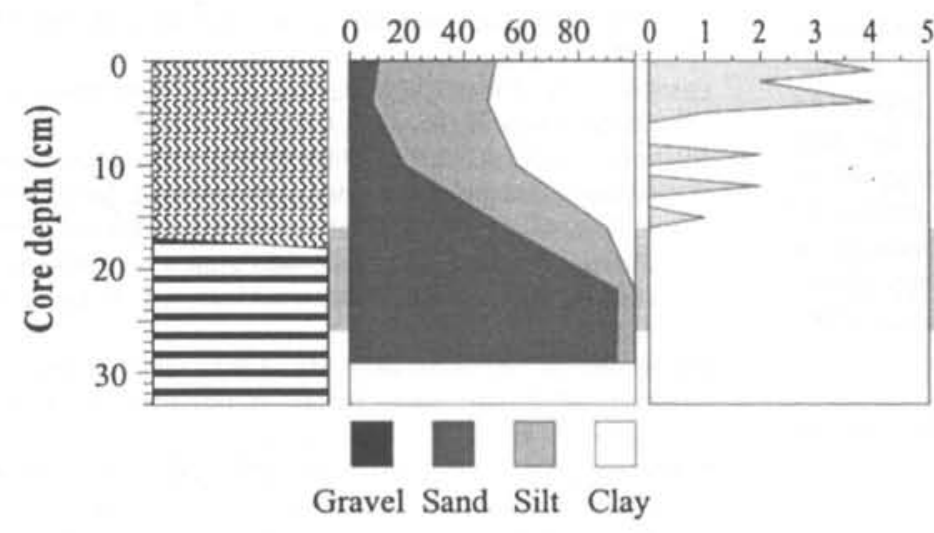

Ice rafted debris (\# gravel $/ 10 \mathrm{~cm}^{3}$ )

\section{X-radiograph \\ (positive)}

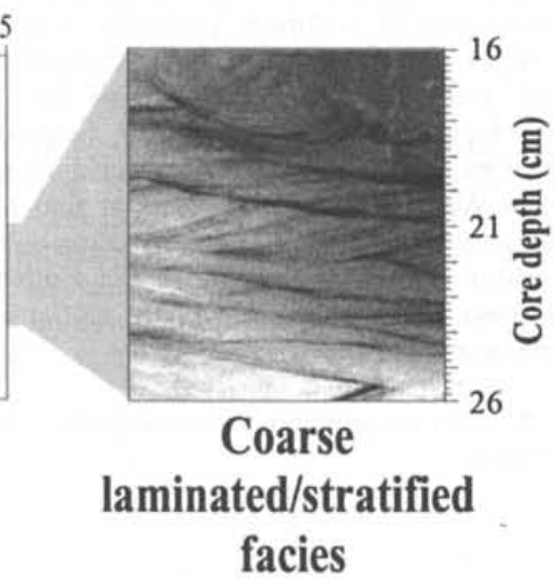

Fig. 6. PS1794 (g).

whereas the distribution of grain sizes in the silt fraction does not show a significant pattern (see core PS1367, Fig. 6a). The granulometric composition of the debris-flow facies is very similar to that of the shelf facies, because debris flows in the Crary Fan area mainly consist of redeposited shelf sediments (see core PS1607 and PS1790, Figs. 6c \& f).

\section{Discussion}

\section{Are there contourites?}

The depositional environment of the laminated and/or clearlystratified sediments along the continental margin of the southeastern Weddell Sea undoubtedly reflects strong current activity. However, it is difficult to decipher whether the currents were of contouritic or turbiditic origin on the basis of grain size and sedimentary structures, because unequivocal criteria for both sediment types are missing.

Even in the seismic profiles it is very difficult to assign the features of the channel-levee systems to either turbiditic or contouritic influence, though Faugères et al. (1999) listed many features diagnostic of contourite drifts and turbidites. The difficulties arise from the fact that the geostrophic and turbidite currents are directed in almost opposite directions (the turbidite channels run to the northeast, thermohaline currents of the Weddell Gyre are directed to the southwest), so that criteria that can be used for distinction of either type (e.g. downstream coarsening or fining of levee sediments or the progradation of the levee from a downslope direction to a course parallel to the slope) add up or overlay each other. However, without doubt the sediments in the southeastern Weddell Sea form combined or intercalated turbidite and contourite sequences.

Holocene sediments are basically characterized by hemipelagic facies, though the modern continental-slope environment in the southeastern Weddell Sea is known to be moderately to highly energetic as a result of the cyclonic currents of the Weddell Gyre. A possible reason for the lack of lamination and weak stratification of hemipelagic sediments may be bioturbation, which did not occur or was less intense during glacial conditions because of perennial sea-ice cover and significantly higher sedimentation rates. This would not rule out a contouritic and/or turbiditic origin, or at least a contouritic and/or turbiditic influence on the deposition of Holocene hemipelagic sediments.

\section{Hydrodynamic interpretation}

The formation of the combined turbidite-contourite levees, as inferred from site survey and sediment data, involves the following processes: Sediment suspensions are generated on the shelf or the upper continental slope by turbidity currents (or the formation of ISW) and move gravitationally down the continental slope, where they are rapidly channelised in a system of channels and gullies. Both turbidity currents and ISW plumes have the ability to entrain sediment and erode along the channel thalweg, depending on the density contrast with surrounding water masses. ISW can reach current velocities exceeding $100 \mathrm{~cm} \mathrm{~s}^{-1}$ (Foldvik \& Gammelsrød 1988). The suspensions in the channels are subject to the vigorous current of the Weddell Gyre and to Coriolis forcing, which together cause a part of the suspension to spill over the northwestern side of the channels. By subsequently losing its sediment load with distance from the channel, the overspill sedimentation builds up a levee along the left flank of the channel. The combined action of contour current and Coriolis force almost completely impedes the formation of a levee on the right, eastern side of the channels. In a succession of several channel-levee systems, the overspill sedimentation of one channel fills up the space before the weakly developed levee along the right side of the next channel, and by this suppresses the emergence of an eastern levee. The grain size of levee deposits and the thickness of the laminae or depositional units, as well as the distance a suspension plume travels down the channel, depend on the magnitude of the suspension event and the availability and supply of sediment at the upper slope, which in turn controls the sedimentation rates. The fact that the broad wedge-shaped form of the levees started to develop with the late Miocene invigoration of thermohaline currents in the Antarctic argues for a strong current influence on levee formation.

The sedimentation rates were significantly different during late Quaternary glacial and interglacial periods. The last glacial showed rates up to 30 times higher than Holocene sedimentation rates (Weber et al. 1994), because the sea level was significantly lower and the grounding line of the Antarctic ice sheet in the southernmost Weddell Sea was located at the shelf edge so that glacial debris was directly discharged to the slope (Grobe \& Mackensen 1992; Bentley \& Anderson 1998; Anderson \& Andrews 1999). With the late-glacial retreat of the ice sheet and the Holocene sea-level rise, additional depositional space became available on the shelf where sediment was stored before reaching 
the slope. During glacial periods, two processes caused a significant increase of sedimentation rates: (1) the reworking of interglacial deposits on the shelf during advances of the ice sheets across the shelf; (2) the release of IRD by calving glaciers when the ice sheet reduced its size during climate warming.

The enormous release of sediment probably triggered mass wasting, slumps, slides, debris flows and turbidity currents. Gravitational processes were more important than the processes involved with the formation of ISW. Further support for this assumption is given by the investigation of water mass properties in the southeastern Weddell Sea, which suggest that northwestward-directed currents measured in certain moorings indicate a recirculation of water masses originating in the Enderby Basin (Hoppema et al. 1998, Fahrbach et al. 1998), rather than ISW flowing downslope in channels.

C. J. Pudsey and J. A. Howe are gratefully acknowledged for their helpful and constructive reviews.

\section{References}

ANDERSON, J. B. \& ANDREWS, J. T. 1999. Radiocarbon constraints on ice sheet advance and retreat in the Weddell Sea, Antarctica. Geology, 27, 179-182.

Anderson, J. B., Brake, C., Domack, E., Myers, N. \& Wright, R. 1983 Development of a polar glacial-marine sedimentation model from Antarctic Quaternary deposits and glaciological information. In MolnIA, B. F. (ed.) Glacial-Marine Sedimentation. Plenum Press, New York, 233-264.

Anderson, J. B., Kurtz, D. D., Domack, E. W. \& Balshaw, K. M. 1980. Glacial and glacial-marine sediments of the Antarctic continental shelf. Journal of Geology, 88, 399-414.

Anderson, J. B., Kurtz, D. D. \& Weaver, F. M. 1979. Sedimentation on the Antarctic continental slope. In: Geology of Continental Slopes. Special Publication of the Society of Economic Paleontologists and Mineralogists, 27, 265-283.

BART, P. J., DE BATIST, M. \& JOKAT, W. 1999. Interglacial collapse of Crary Trough-Mouth Fan, Weddell Sea, Antarctica: Implications for Antarctic glacial history. Journal of Sedimentary Research, 69(6), 1276-1289.

Barker, P. F., Kennett, J. P. ET AL. 1988. Proceedings of the ODP, Initial Reports, Leg 113. Ocean Drilling Program, College Station, TX.

Barker, P. F., Kennett, J. P. et AL. 1990. Proceedings of the ODP, Scientific Results, Leg 113. Ocean Drilling Program, College Station, TX.

BENTLEY, M. J. \& ANDERSON, J. B. 1998. Glacial and marine geological evidence for the ice sheet configuration in the Weddell Sea-Antaretic Peninsula region during the Last Glacial Maximum. Antarctic Science, 10, 309-325.

British ANTARCTIC Survey 1985. Tectonic map of the Scotia Arc, 1:3,000,000. BAS (Misc) 3, Cambridge.

CARMACK, E. C. \& Foster, T. D. $1975 a$. On the flow of water out of the Weddell Sea. Deep-Sea Research, 22, 711-724.

CARMACK, E. C. \& Foster, T. D. 1975b. Circulation and distribution of oceanographic properties near the Filchner Ice Shelf. Deep-Sea Research, 22, 77-90.

CARMACK. E. C. \& Foster, T. D. 1977. Water masses and circulation in the Weddell Sea. In: DunBar, M. J. (ed.) Proceedings of the Polar Oceans Conference, Montreal, 151-165.

DeAcon, G. E. R. 1979. The Weddell Gyre. Deep-Sea Research, 26A. 981-995.

Diekmann, B. \& Kuhn, G. 1997. Terrigene Partikeltransporte als Abbild spätquartärer Tiefen- und Bodenwasserzirkulation im Südatlantik und angrenzendem Südpolarmeer. Zeitschrift der deutschen Geologischen Gesellschaft, 148, 405-429.

Diekmann, B. \& KunN, G. 1999. Provenance and dispersal of glacialmarine surface sediments in the Weddell Sea and adjoining areas, Antarctica: ice-rafting versus current transport. Marine Geology, 158 209-231.

Diekmann, B., Kuhn, G., Mackensen, A., Petschick, R., Futterer, D. K., Gersonde, R., Rühlemann, C. \& Niebler, H.-S. 1999. Kaolinite and chlorite as tracers of modern and Late Quaternary deep-water circulation in the South Atlantic and the adjoining southern ocean. In: Use of proxies in palaeoceanography: Examples from the South Atlantic. Springer, Berlin, 285-313.

Ehrmann, W. U., Melles, M., Kuhn, G. \& Grobe, H. 1992. Significance of clay mineral assemblages in the Antarctic Ocean. Marine Geology, 107, 249-273.

ElVERHøI, A. 1981. Evidence for a late Wisconsin glaciation of the Weddell Sea. Nature, 293, 641-642.

Elverhøi, A. \& MAISEY, G. 1983, Glacial erosion and morphology of the eastern and southeastern Weddell Sea shelf. In: OLIVIER, R. L., JAMES, P. R. \& Jago, J. B. (eds) Antarctic Earth Science, Proceedings of the Fourth International Symposium Antarctic Earth Science, Adelaide, Australia 1982. Australian Academy of Science, Canberra 1983, 483-487.

ElverhøI, A. \& RoAldset, E. 1983. Glaciomarine sediments and suspended particulate matter, Weddell Sea shelf, Antarctica. Polar Research, 1, 1-21.

FAHRBACH, E. \& ROHARDT, G. 1988. Moored instrument data, In: FAHRBACH, E. (ed.) Meteorological and Oceanographic Data of the Winter Winter-Weddell-Sea Project 1986 (ANT K/3). Berichte zur Polarforschung, 46.

Fahrbach, E., Rohardt, G. \& Krause, G. 1992. The Antarctic Coastal Current in the southeastern Weddell Sea. Polar Biology, 12, 171-182.

Fahrbach, E., Rohardt, G., Schröder, M. \& Strass, V. 1994. Transport and structure of the Weddell Gyre. Annales Geophysicae, 12, 840-855.

Fahrbach, E., SChröder, M. L. \& Klepikov, A. 1998. Circulation and water masses in the Weddell Sea. In: LePpäranta, M. (ed.) Physics of Ice-Covered Seas. Lecture notes from a summer school in Savonlinna, Finland, Helsinki University, 569-603.

Faugères, J.-C., Stow, D. A. V., Imbert, P. \& VianA, A. 1999. Seismic features diagnostic of contourite drifts. Marine Geology, 162, 1-38.

FOLDVIK, A., GAMMELSRøD, T. \& TøRRESEN, T. 1985. Circulation and water masses on the southern Weddell Sea Shelf. In: Oceanology of the Antarctic Continental Shelf. Antarctic Research Series, 43, 5-20.

FoldVIK, A. \& GAMmELSRøD, T. 1988. Notes on southern ocean hydrography, sea ice and bottom water formation. Palaeoceanography, Palaeoclimatology, Palaeoecology, 67, 3-17.

Foster, T. D. \& MidDLETON, J. H. 1979. Variability in the bottom water of the Weddell Sea. Deep-Sea Research, 26, 743-762.

Fotterer, D. K. \& Melles, M. 1990. Sediment patterns in the southern Weddell Sea: Filchner Shelf and Filchner Depression. In: BLEIL, U. \& THIEDE, J. (eds) Geological History of the Polar Oceans: Arctic vs. Antarctic. NATO/ASI Series C, Kluwer Academic Press, Dordrecht, Netherlands, $381-401$.

FútTerer, D. K., Grobe, H. \& Grünig, 1988. Quaternary sediment patterns in the Weddell Sea: relations and environmental conditions. Palaeoceanography, 3(5), 551-561.

Futterer, D. K., KuhN, G. \& SCHENKE, H. W. 1990. Wegener Canyon bathymetry and results from rock dredging near ODP sites 691-693, eastern Weddell Sea, Antarctica. In: BARKER, P. F. \& KeNNETT, J. P. ET AL. (eds) Proceedings of the Ocean Drilling Program, Scientific Results. Ocean Drilling Program, College Station, TX, 113, 39-48.

Gersonde, R., Abelmann, A., ET AL. 1990. Biostratigraphic synthesis of Neogene siliceous microfossils from the Antarctic Ocean, ODP Leg 113 (Weddell Sea). In: Barker, P. F. \& Kennett, J. P. et AL. (eds) Proceedings of the Ocean Drilling Program, Scientific Results. Ocean Drilling Program, College Station, TX, 113, 915-936.

Gloersen, P., Campbel.l, W. J., Cavalieri, D. J., Comiso, J. C., Parkinson, C. L. \& Zwally, H. J. 1992. Arctic and Antarctic sea ice, 1978-1987; Satellite passive microwave observations and analysis. NASA SP-511.

Gordon, A. L. 1982. Weddell Deep Water variability. Journal of Marine Research, Supplement, 40, 199-217.

Gordon, A. L., MARTINSON, D. G. \& TAYLOR, H. W. 1981. The wind-driven circulation in the Weddell-Enderby Basin. Deep-Sea Research, 28A, $151-163$.

Grobe, H., Mackensen, A., Hubberten, H.-W., Spiess, V. \& Fútterer, D. K. 1990a. Stable isotope record and late Quaternary sedimentation rates at the Antarctic continental margin. In: BLEIL, U. \& THIEDE, J. (eds) Geological History of the Polar Oceans: Arctic vs. Antarctic. NATO/ASI Series C, Kluwer Academic Press, Dordrecht, Netherlands, 539-560. 
Grobe, H., Fütterer, D. K. \& SPIEB, V. 1990b. Oligocene to Quaternary sedimentation processes on the Antarctic continental margin, ODP Leg 113, Site 693. In: Barker, P. F. \& Kennett, J. P. et al. (eds) Proceedings of the Ocean Drilling Program, Scientific Results. Ocean Drilling Program, College Station, TX, 113, 121-131.

Grobe, H. \& Mackensen, A. 1992. Late Quaternary climatic cycles as recorded in sediments from the Antarctic continental margin. In Kennett, J. P. \& Warnke, D. A. (eds) The Antarctic Palaeoenvironment: A Perspective on Global Change. Antarctic Research Series, 56. 349-376.

HenRIET, J. P. \& Miller, H. 1990. Some speculation regarding the nature of the Explora-Andenes Escarpment. In: BLEIL, U. \& THIEDE, J. (eds) Geological History of the Polar Oceans: Arctic vs. Antarctic. NATO/ASI Series C, Kluwer Academic Press, Dordrecht, Netherlands, 163-172.

Hinz, K. \& Krause, W. 1982. The continental margin of Queen Maud Land/Antarctica: Seismic sequences, structural elements, and geological development. Geologisches Jahrbuch, E23, 17-41.

Hollister, C. D. \& Elder, R. B. 1969. Contour currents in the Weddell Sea. Deep-Sea Research, 16, 99-101.

Hoppema, M., Fahrbach, E., Richter, K.-U., de BaAR, H. J. W. \& KATTNER, G. 1998. Enrichment of silicate and $\mathrm{CO}_{2}$ and circulation of the bottom water in the Weddell Sea. Deep-Sea Research, I 45 , $1797-1817$.

KUHN, G. \& WEBER, M. 1993. Acoustical characterization of sediments by Parasound and $3.5-\mathrm{kHz}$ systems: Related sedimentary processes on the southeastern Weddell Sea continental slope, Antarctica. Marine Geology, 113, 201-217.

KuhN, G., SCHENKE, H.-W. \& FUTterer, D. 1995. The Weddell Fan: A complex channel/ridge-system in the southern Weddell Sea, Antarctica. In: The role of palaeoceanographic linkages in the global system. 5 th International Conference on Palaeoceanography, Halifax, Nova Scotia, Canada, 163-164.

KUVAAS, B. \& KRISTOFFERSEN, Y. 1991. The Crary Fan: a trough-mouth fan on the Weddell Sea continental margin, Antarctica. Polar Research, 7, $43-57$.

Mackensen, A., Grobe, H., Hubberten, H. \& Kuhn. G. 1994. Benthic foraminiferal assemblages and the $813 \mathrm{C}$-signal in the Atlantik sector of the Southern Ocean: Glacial-to-interglacial contrasts. In: ZAHN, R. (ed.) Carbon Cycling in the Glacial Ocean: Constraints on the Ocean's Role in Global Change. NATO ASI Series, I 17, Springer, Berlin, 105-144.

MELLES, M. 1991. Late Quaternary palaeoglaciology and palaeoceanography at the continental margin of the southern Weddell Sea, Antarctica. Berichte zur Polarforschung, $\mathbf{8 1 .}$

Melles, M. \& KuHN, G. 1993. Sub-bottom profiling and sedimentological studies in the southern Weddell Sea, Antarctica: evidence for largescale erosional/depositional processes. Deep-Sea Research, 40(4), 739-760.

Melles, M., Kuhn, G., Futterer, D. K. \& Meischner, D. 1995. Processes of modern sedimentation in the southern Weddell Sea, Antarctica Evidence from surface sediments. Polarforschung, 64, 45-74.
Miller, H., Henriet, J. P., Kaul, N. \& MoOns, A. 1990. A fine-scale seismc stratigraphy of the eastern margin of the Weddell Sea. In: BLEIL, U. \& THIEDE, J. (eds) Geological History of the Polar Oceans; Arctic vs. Antarctic. NATO/ASI Series C, Kluwer Academic Press, Dordrecht, Netherlands, 131-161.

Moons, A., De Batist, M., Henriet, J. P. \& Miller, H. 1992. Sequence stratigraphy of the Crary Fan, southeastern Weddell Sea. In: Yoshida, Y., Kaminuma, K. \& Shiraishi, K. (eds) Recent Progress in Antarctic Earth Science. Tokyo, 613-618.

OszKó, L. 1997. Tectonic structures and glaciomarine sedimentation in the south-eastern Weddell Sea from seismic reflection data. Berichte zur Polarforschung, 222.

Petschick, R., KuhN, G. \& Gingele, F. 1996. Clay mineral distribution in surface sediments of the South Atlantic: sources, transport, and relation to oceanography. Marine Geology, 130, 203-229.

Rebesco, M., Larter, R. D., Camerlenghi, A. \& Barker, P. F. 1996. Giant sediment dirfts on the continental rise west of the Antarctic Peninsula. Geo-Marine Letters, 16, 65-75.

Rebesco, M., Larter, R. D., Barker, P. F., Camerlenghi, A. \& VANNESTE, L. E. 1997. The history of sedimentation on the continental rise west of the Antarctic Peninsula. In: Geology and Seismic Statigraphy of the Antarctic Margin, Part 2. Antarctic Research Series, 71, 29-49.

Rohardt, G., Fahrbach, E., Krause, G, \& Strass, V. H. 1992. Moored current meter and water level recorder measurements in the Weddell Sea 1986-1990. Berichte Fachbereich Physik, 28, Alfred Wegener Institute, Bremerhaven.

Schenke, H. W., Dijkstra, S., Niederiasper, F., Schöne, T., Hinze, H. \& Hoppmann, B. 1998. The New Bathymetric Charts of the Weddell Sea: $A W I$ BCWS. American Geophysical Union, Antarctic Research Series 75, 371-380 + map.

SChlitzer, R. 1999. Ocean Data View. World Wide Web Address: http://www.awi-bremerhaven.de/GEO/ODV.

Sea ICE Climatic Atlas 1985. Vol. 1, Antarctic. Prepared by Naval Oceanography Comand Detachment, Asheville, NSTL, MS $39527-$ 5000.

TINGEY, R. J. 1991. Schematic geological map of Antarctica, Scale 1:10,000,000 (commentary and map). Department of Primary Industries and Energy, Bureau of Mineral Resources, Geology and Geophysics, Bulletin 238. Australian Government Publishing Service, Canberra.

WEBER, M. 1992. Late Quaternary sedimentation at the continental margin of the southeastern Weddell Sea, Antarctica. Berichte zur Polarforschung, 109.

Weber, M. E., Bonani, G. \& Fútterer, K. D. 1994. Sedimentation processes within channel-ridge systems, southeastern Weddell Sea, Antarctica. Palaeoceanography, 9, 1027-1048.

Zwally, H. J., Comiso, J. C., Parkinson, C. L., CAmpbell, W. J., Carsey, F. D. \& Gloersen, P. 1985. Antarctic Sea Ice, 1973-1976: Satellite Passive-Microwave Observations. NASA Special Publication, 459. 